\title{
Stalin's Faminogenic Policies in Ukraine: The Imperial Discourse
}

\author{
Liudmyla Hrynevych \\ Institute of the History of Ukraine, National Academy of Sciences of Ukraine
}

\section{Translated from Ukrainian by Andrew Sorokowski}

\begin{abstract}
Because Stalin's policy of famine creation in the early 1930s has been viewed through the prism of communist theory and practices, scholars have paid less attention to the imperial/colonial discourse of the period. This essay attempts to show the suitability of applying theoretical models of dependence and imperialism to analyze the dynamics and consequences of the collectivization of agriculture and the Holodomor (the mass deaths through starvation in Ukraine). The pressure applied to all regions of the USSR, resulting from the "communist experiment," was in Soviet Ukraine supplemented and intensified, and, at some points, determined by a system of centre-periphery relations, characterized by political domination, control, the subordination of regional political elites to the centre, and the exploitation of economic resources. The appropriation of sovereignty over the Ukrainian republic by the central government in Moscow included establishing full control over Ukraine's food resources, such as determining grain harvesting and distribution. The ongoing exploitation of Ukrainian economic resources and the antiUkrainian terror caused the Ukrainian famine of 1928-29. These also became significant factors in the onset of the 1932-33 Holodomor.
\end{abstract}

Keywords: faminogenic policy, ${ }^{1}$ Holodomor, genocide, Ukraine, famine, imperialism, colonialism.

$\mathbf{I}^{\mathrm{n}}$

$\mathbf{n}$ the last thirty years, our knowledge and understanding of the causes and nature of Stalin's famine-inducing policies in Ukraine have grown significantly (Applebaum; Kulchytsky; Kul'chyts'kyi; Mace; Makuch and Sysyn). Nevertheless, while the 1932-33 famine in Ukraine, known as the Holodomor, has been examined through the prism of theories and practices of communism and totalitarianism, it has for the most part remained outside of academic discussion of imperial and colonial discourses.

Given that for decades Stalinist faminogenic policies were not the subject of scholarly attention, the study of the Holodomor is only beginning

\footnotetext{
1 The term "faminogenic" was coined by David Marcus to describe state policies and activities that create famine conditions or support their creation (245n 9).
} 
to benefit from theoretical models that could contribute to understanding its complexities. In addition, the academic community is far from unanimous in how concepts of empire and colonialism apply to the USSR. Finally, political and psychological factors must be taken into account. Since the time of the Cold War, the "politicization" of the topic of the Ukrainian famine of the early 1930s has received attention, with the terms "Soviet empire," "Soviet imperialism," and "Soviet colonial practice" sometimes employed for political purposes. The combination of these factors, I would argue, has shaped a reluctance in academia to discuss the Ukrainian famine in terms of imperialism and colonialism.

Paradoxically, for decades the USSR built its ideology upon anti-imperial and anti-colonial rhetoric. As noted by Ronald Suny, the denial of its own imperial nature made the Soviet Union a truly unique empire in the twentieth century (191). With the dissolution of the USSR and the rise of nation-states upon its ruins, interest in "empire studies" in general and in the imperial nature of the Soviet Union in particular increased significantly.

There are three basic approaches to addressing the question of the imperial nature of the USSR. The majority of scholars in North America and Europe consider the Soviet Union as a state of the imperial type (Applebaum; Etkind; Hirsch; Hosking; Kappeler, The Russian Empire; Lieven; Martin; Vishnevskii). Some scholars propose that the USSR be regarded as a hybrid entity: both an empire and a nation state (Kaspe). Finally, there are researchers who preserve a view of Soviet history that is nation-state oriented, ignoring the imperial essence of the USSR (Tishkov).

Contemporary scholars have proposed various typological designations of the Soviet empire: polyethnic (Kappeler), neo-Russian (Hosking), colonial (Thompson), post-colonial (Etkind), post-theocratic (Iakovenko), uninterrupted and totalitarian (Motyl), an affirmative action empire (Martin), an empire of nations (Hirsch), and an authoritarian and disciplinary empire (Batalov 12), among others. As well, scholars have expressed different and, at times, diametrically opposed views regarding the status and role of the Ukrainian SSR in the Soviet Union, especially as to the question of its colonial nature. Here the spectrum of opinions is particularly wide, from declaring Ukraine part of an "East Slavic metropolia" within "Great, Little, and White Rus'” (Vishnevskii 278-79) to confidently designating it as a typical peripheral colony (Motyl').

These discussions are further complicated by the absence of scholarly consensus on classification criteria and typological markers, or even on the definition of the concept of "empire" itself. Dominic Lieven describes the methodological difficulties in arriving at clear formulas that capture the phenomenon of empire in all its complexity. "Empire," he writes, "is a fine subject, peopled by leopards and other creatures of the wild. To reduce all this to definitions and formulas is to turn the leopard into a pussycat, and 
even then into an incomplete but misshapen pussycat with three legs and no tail" (Lieven 417). Of key significance is the nature of relations between the centre (metropolia) and the periphery (colony), which Michael Doyle describes as "a relationship, formal or informal, in which one state controls the effective political sovereignty of another political society. It can be achieved by force, by political collaboration, by economic, social, or cultural dependence" (45).

This essay aims to stimulate academic discussion on the topic of whether one can view Stalin's faminogenic policies in Ukraine in the late 1920 s and early 1930s through the prism of imperial discourse. It compares the Holodomor with other instances of "imperial" famines in modern world history. My key thesis is that theoretical models of dependence and imperialism can be employed fruitfully to elucidate important aspects of the Stalinist policies that created famine in the national republics and, in particular, the Holodomor of 1932-33 in Ukraine. It is my belief that in the epoch of Stalin's "revolution from above" and the Holodomor, the pressure resulting from the "communist experiment," indisputably shared by all regions of the USSR, was amplified and at certain moments defined by a system of centre-periphery relations characterized by political domination and control, and exploitation of economic resources (in this case, food resources, grain being chief among them). This circumstance (in interaction with anti-Ukrainian terror, the analysis of which is beyond the scope of this article) became the essential factor leading to mass human mortality during the Holodomor.

In my work, I rely primarily on the theories of dependence and imperialism developed by Doyle and the theoretical approaches and evaluations formulated by Alexander Motyl and Lieven. In his article "The Soviet 1931-1933 Famines and the Ukrainian Holodomor: Is a New Interpretation Possible, and What Would Its Consequences Be?" Andrea Graziosi points to the imperial factor as key to understanding Stalinist faminogenic policies, emphasizing the need to differentiate famine as an allUnion phenomenon in 1931-33 from the Holodomor in Ukraine, the unique consequences and dynamics of which were a direct result of Moscow's decisions. This raises the question: to what degree can the Stalinist policies that led to famine, be seen as a means of consolidating the Soviet empire and ensuring its existence through violence?

In pursuing the research goal outlined above, this article addresses the following tasks (insofar as the limited scope of an article permits). A brief excursus into the history of the Russian Empire is in order to elucidate the role of the Ukrainian gubernias as leading grain-producing and grainexporting regions and to sketch out in general terms the nature of relations between the central government of Russia and Ukraine during the processes of modernization. I then turn to an examination of the circumstances of the 
fall of the Russian Empire, the appearance of the Ukrainian People's Republic as a national state-building project, and the formation of the Soviet empire, including particular features of its expansionist policy vis-a-vis Ukraine. Next, citing hitherto unknown archival documents, I examine the manifestations of political and economic inequality in the relations between the all-Union (central) government and the Ukrainian SSR, focusing on the famine of 1928-29 and then touching on the Holodomor of 1932-33 in Soviet Ukraine. Finally, I will consider how these events were perceived by representatives of various social strata at the time, from the peripheral elite to ordinary people. In particular, I address the question of whether Stalin's faminogenic policies were understood by the population as manifestations of Moscow's imperial rule and of Ukraine's colonial dependence.

UKRAINE IN THE RUSSIAN EMPIRE AS THE BREADBASKET OF EUROPE: POSSIBILITIES AND LIMITS

Before World War I, the Ukrainian gubernias produced 25 percent of the grain in the Russian Empire, close to 30 percent of the wheat, 40 percent of the barley, and nearly 50 percent of the beans and corn (Kontrol'nye tsifry 41). Ukraine (chiefly its steppe zone) provided nearly one-eighth of the world's imports in the five principal seed crops (wheat, rye, barley, oats, and corn) and thus was a significant force in producing profits to fund the modernizing of the empire.

The proportion of Ukrainian grain on the world market was particularly notable for certain crops. Barley and rye constituted a third, while wheat and wheat flour made up nearly a ninth. Ukrainian wheat seed was exported to European countries-England, France, Italy, Germany-while flour was shipped to Turkey, Greece, and Egypt. Germany purchased the greatest portion of the rye and barley exported from Ukraine, and France and England imported the greatest portion of Ukrainian oats. Ukrainian corn was shipped to England, Germany, and the Netherlands. France, Germany, and the Netherlands bought beans. ${ }^{2}$ It is thus no wonder that before World War I, Ukraine was sometimes referred to as the "breadbasket of Europe," and any news of poor weather or possible crop failure in the steppe gubernias disturbed the world grain market, causing a jump in prices.

And yet, despite their great potential, the Ukrainian lands of the Russian Empire suffered from underdevelopment. As Lieven has observed, entering the age of industrial modernization, the Russian Empire, which combined

${ }^{2}$ Al'terman 21-22. On the export policy of the Russian Empire, see Den; Shevchenko; and Thompstone. 
the traits of European overseas colonies and the characteristics of an autocratic land empire, long remained economically and politically backward. The Russian Empire possessed nearly a third of the earth's arable land. Yet, it provided little more than a fifth of the global grain yield (21.8 percent in 1910-14) (Den 46). Compared with other grain-producing countries, the crop yield was extremely low. According to data from the international agricultural institute in Riga, in 1905-14 Russia had the lowest average yield per hectare (in quintals) for the six chief crops (wheat, rye, barley, oats, corn, and sugar beets). The situation with wheat is illustrative. During these years, the average yield was 30.2 in Denmark, 24.5 in Belgium, 21.8 in Great Britain and Ireland, 20.6 in Germany, and 13.6 in France, while in European Russia it was 6.6. The French harvested twice as much wheat, and the British and Germans, three times as much. The Russian Empire was last not only in comparison with industrially developed countries but also compared to those with extensive agricultural development, even colonies and former colonies: during the four pre-war decades, the wheat harvest in Canada, for example, yielded 12.8 quintals per hectare; in Australia, 7.6; and in British India, 7.7 (Den 48).

An indicator of the backwardness of the Russian Empire was the fact that its population constantly suffered from an insufficiency of grain resources, especially during the frequent crop failures. The years 1891-92, 1897-98, 1901, 1905-06, and 1911 clearly confirm this, at the same time demonstrating the difference between the situation in the Russian Empire and that in the more developed European countries, where crop failures meant lower profits but no longer caused famine among the population. The Russian Empire too, however, gradually evolved in this direction, chiefly in its Ukrainian gubernias: as agronomists observed, they "stood above the greater part of the rest of the Russian gubernias not only in population density, industrial development, and concentration of the population in the cities, but also in the superiority of their agriculture" (TsDAVO $337 / 1 / 8085 / 2$ ).

In fact, after the 1880s the number of major crop failures in the Kyiv, Podillia, Poltava, Kherson, Iekaterynoslav, and Tavriia gubernias, as well as in the Don region, fell by half (1880s: 11, 1890s: 2, 1900-15: 3) (TsDAVO $337 / 1 / 8085 / 8$ ), while from 1883 to 1915 , the crop yield in the Ukrainian gubernias rose significantly, in most by a factor of two and even more (TsDAVO 337/1/8085/4).

Before the beginning of World War I, the crop yields of the principal grains in the three Ukrainian gubernias was the highest among the fifty gubernias of European Russia: 84.4 puds ( 1 pud $=36.11$ pounds) per desiatyna (1.1 hectares or 2.7 acres) in the Kyiv gubernia, 81.8 puds in the Podillia gubernia, 72.2 puds in the Poltava gubernia. In the Volhynia, Iekaterynoslav, and Kharkiv gubernias, over 60 puds per desiatyna were 
gathered; the Tavriia gubernia was sixteenth (54.8 puds per desiatyna); and the Kherson gubernia, nineteenth (54.3 puds per desiatyna) (TsDAVO $337 / 1 / 8085 / 3$ ).

Nevertheless, by the beginning of the twentieth century, the Ukrainian lands within the empire had reached the peak of their crop yield and export capabilities. The combination of a practical exhaustion of the fund of virgin soil, sharp rise in industry, and increase in the urban population made a reduction of marketable grain from the Ukrainian gubernias inevitable. It became evident that any increase in the size of the harvest would be dependent on the intensification of agricultural production. At the same time, the orientation toward external markets-and as a result, the growing predominance of grain production in Ukraine, with the accent on wheat and barley as the chief cash crops (in 1916, they constituted 29.1 percent and 23.3 percent, respectively, in the sowing area of the Ukrainian gubernias, and in the steppe zone, 36.7 percent and 35 percent)—did not foster a rise in agricultural production (Vol'f and Mebus 69). In fact, the increasing focus on exporting grain undermined the development of cattle breeding, which contributed to the exhaustion of fertile lands.

Hard currency obtained through exports was prioritized for the modernization of the industrial base of the Russian Empire despite the chronic undernourishment of the population. The phrase "we will go hungry, but we will export," attributed to the minister of finance Ivan Vyshnegradskii (1832-95), conveys the essence of imperial government policy on the eve of World War I: in 1909-13, each year an average of 323.8 million puds of grain was removed from Ukraine, of which only 55.2 million puds ended up on the empire's internal markets, while the rest was exported (Al'terman 21).

As Austrian historian Andreas Kappeler notes, the colonial nature of the polyethnic Russian Empire intensified along with modernization (Rosiia 249). Accordingly, Ukraine more clearly took on the traits of a colonial/dependent territory. The centre extracted finances and raw materials from the Ukrainian gubernias more and more energetically, at the same time taking advantage of them as a market for production from Russia that was not competitive on world markets.

In the pre- and especially the post-revolution years, Ukrainian scholars and civic activists were attentive to the marked disproportions in the relations between the centre (Moscow) and Ukraine, to the detriment of the latter. Not infrequently, these relations were termed colonial and served as an argument for Ukrainian autonomy. For example, Oleksandr Mytsiuk, in his brochure Pro avtonomiiu Ukrainy v federatyvnii Rosii (On the Autonomy of Ukraine in a Federal Russia), which became the notes for two public lectures he delivered in 1917 in Kyiv, pointed out that in 1903, 519 million rubles were transferred from Ukraine to the state treasury, while only 279 million rubles were expended for Ukraine's needs. Accordingly, 240 million 
rubles, that is, 46 percent of Ukrainian revenues, were spent on the needs of other regions. The author compared the situation with the fate of "luckless Ireland, which in the course of centuries of English oppression has lost even its native old-Celtic language" (Mytsiuk 17).

Other Ukrainian experts expressed similar thoughts. Analyzing statistical data for 1900-13, the economist and social activist Petro Mal'tsiv pointed out that the portion of revenue received from Ukraine constituted, on average, 20.8 percent of the overall Russian amount, while expenses came to only 11.8 percent (Iefimenko 38). L. Bukhanovs'kyi published data showing that in the Russian Empire between 1900 and 1914, an average of 16 rubles 97 kopecks was received annually from each inhabitant of Ukraine, while the state spent 8 rubles 65 kopecks per inhabitant. In comparison, in Russia, the amount received per inhabitant was 13 rubles 90 kopecks and 13 rubles 99 kopecks was expended (Iefimenko 38).

In a study published in Petrograd in 1918, the scholar and publicist Petro Stebnyts'kyi noted another problem: "Ukraine supplies the neighbouring districts with raw materials and semi-manufactured goods, and itself serves as a market for their finished products" (18). The following data supports the assertion: in 1915-16, 96.7 percent of Ukraine's rolled metal, 68 percent of its shaped metal, 99 percent of its I-beams and U-bars, 53 percent of its salt, 81 percent of its tin, 90 percent of its silver, and 75 percent of its general supplies of cast iron went to factories in Russia (V. Hrynevych et al. 85). In his detailed analysis of economic relations, Stebnyts'kyi concluded that in the pre-war years, imperial policy toward Ukraine had assumed the character of colonial exploitation:

The entire system of Russia's posture toward Ukraine is analogous to the relationship of a metropolia imbued with imperialistic tendencies and a colony, which aspires to emancipate itself from the oppression that it experiences on the part of the metropolia. Of course, official Russia, proceeding in its policy from the idea of state and national unity, did not consciously treat Ukraine as a colony and did not aim at its economic exploitation. But such is the power of the centralizing principle that, in spite of the desires of the circles which direct economic life, economic imperialism grows independently in close connection with political imperialism, and under its pressure, urgent interests are muted and the vital powers of the peripheries atrophy. In the national question, old Russia always consciously conducted a policy that was hostile to Ukraine and its culture. (36-37).

Finally, with the onset of modernization in the second half of the nineteenth century, two disparate tendencies, which increased political and social tensions, were growing and also becoming more visible in the polyethnic Russian Empire at the start of the twentieth century (Kappeler, 
Rosiia 247). On the one hand, the centre desired to achieve uniformity based on Russian ethnic dominance. On the other hand, diversity was enhanced by the social and national mobility of the numerous non-Russian ethnic groups, which were gradually turning into contemporary nations with their own elites, literary languages, and highly developed cultures (Kappeler, Rosiia 247). In the new epoch of nation states, these contradictions would wind themselves into a tight knot that the imperial government could not untie and that would contribute to the fall of tsarist Russia.

THE FALL OF THE RUSSIAN EMPIRE, THE FORMATION OF A UKRAINIAN NATIONAL STATE, THE BIRTH OF THE RED EMPIRE AND ITS EXPANSION INTO UKRAINE

World War I was the catalyst of fundamental changes, as the era of nation states began to succeed the era of empires. After the fall of the Russian Empire and the revolution of 1917, the Ukrainian national movement, which rapidly became a mass movement, made itself heard. ${ }^{3}$ World War I and the revolution accelerated the process of the formation and consolidation of the Ukrainian nation. Like other European nations, the Ukrainians took up the construction of their own nation state, establishing first the Ukrainian Central Rada as its parliament, which then formed Ukraine's autonomous government-the General Secretariat of the Ukrainian People's Republic (UNR). ${ }^{4}$

The Bolshevik seizure of power in Petrograd in the fall of 1917 hastened the rupture of Ukraine and Russia. In its Fourth Universal (January 1918), the Ukrainian Central Rada declared Ukraine to be an independent state. With the signing of the Brest-Litovsk peace treaty in March 1918, the government of the Russian SFSR acknowledged this. Lenin's government

3 On the creation of the Ukrainian People's Republic and the Bolshevik invasion of Ukraine, see Reshetar; Borys; and Kappeler. Rosiia 273. See also the collection of essays in Hunczak.

4 Ukrains'ka Tsentral'na rada, vol. 2; Dyrektoriia. Contemporary Russian historiography has traditionally minimized the role of the Ukrainian revolution and the UNR as a nation state. While the significance of the UNR as a project of Ukrainian state building is acknowledged in the works of some Western specialists on Russia, these sometimes include claims about its brief existence. For example, in Rulers and Victims: The Russians in the Soviet Union, British historian Geoffrey Hosking writes that the UNR lasted three months, when in fact, after a short hiatus (during the period after the declaration of the Ukrainian State of Hetman Pavlo Skoropads'kyi), the UNR was renewed (16). Its government left Ukrainian territory at the beginning of the 1920s under Bolshevik pressure and continued its existence abroad as a government in exile. It formally ceased to exist in 1992 with the creation of an independent Ukrainian state. 
thereby obligated itself to recognize the right of the Ukrainian people to selfdetermination and the legality of the Ukrainian Central Rada's rule over the territory of Ukraine. In supporting Ukraine, the governments of the Central Powers undoubtedly considered Ukraine's status since pre-revolutionary times as a producer and potential supplier of foodstuffs, chiefly grain. Their desire for access to grain prompted them to support a regime change in Ukraine in the spring of 1918 and the creation of the Hetmanate of Pavlo Skoropads'kyi. ${ }^{5}$

Ukraine's declaration of independence triggered war with Soviet Russia, which sent its armies into Ukraine in January 1918. The determination of Lenin's government to keep Ukraine under Russia's control had not only ideological but purely pragmatic motives-access to essential resources. "For god's sake, use the most energetic and revolutionary means to send bread, bread, bread!!! Otherwise St. Petersburg may perish. Special trains and detachments. Collection and amassing. Accompany the trains. Report every day. For god's sake!" wrote Lenin on 15 (28) January 1918 to the extraordinary commissar of the Russian SFSR Council of People's Commissars in Ukraine, Serho Ordzhonikidze, in Kharkiv, and the commander of the southern Bolshevik forces Vladimir Antonov-Ovsienko (30).

During January-April 1918 over 17.3 million puds of grain and 5 million puds of other foodstuffs (meat, bacon fat, sugar, and oil) were shipped from Ukraine to Russia. In January 1918 alone, detachments of the People's Commissariat of Food Supply headed by G. N. Kudinskii dispatched 240 train cars of grain and 140,000 puds of sugar; at the beginning of February, 200,000 puds of flour and 40,000 puds of sugar. At the beginning of March 1918, Kudinskii informed Lenin by telegram that his food supply detachments had sent thirteen regular trains with close to 500,000 puds of grain to Petrograd (V. Hrynevych et al. 85). According to a statement by Lenin himself, Moscow succeeded in procuring 95 million puds of grain from Ukraine in 1918 (V. I. Lenin pro Ukrainu 213).

In late 1918, after the capitulation of Germany, Soviet Russia simply annulled the peace treaty of Brest-Litovsk and resumed its offensive in Ukraine. Simulacra of Ukrainian national governments, and a Ukrainian state created under Moscow's aegis (first, a Soviet UNR, then, by analogy with the RSFSR, a Ukrainian SSR), provided a cover of legitimacy. As in 1918, the advance into Ukraine was accompanied by requisitioning of foodstuffs and their shipment to the north. Although there is no precise information on how much grain Russia managed to ship out of Ukraine into the RSFSR during

\footnotetext{
5 For a detailed discussion, see Malynovs'kyi; Rafalovs'kyi; Borisov et al.
} 
1919, the Ukrainian scholar Hennadii Iefimenko, relying on data available in Soviet historiography, estimated at least ten million puds (130).

The second attempt of Soviet Russia to establish Soviet rule over Ukraine likewise failed. In a letter of 12 November 1919 to the Central Committee of the Russian Communist Party (Bolsheviks) and personally to Lenin, a group of Ukrainian Bolsheviks, analyzing the reasons, noted "a policy that cannot be characterized otherwise than as colonial." "Ukraine," they wrote, "has been regarded exclusively as an object for the extraction of material resources." 6

In 1920, the expansion of Soviet Russia into Ukraine was finally successful. Lenin's government had to declare respect for national rights while bringing in substantial contingents of the Russian SFSR's Red Army onto Ukrainian territory. A census of the Red Army and Fleet conducted in August 1920 showed that "the armies of the Ukrainian gubernias were characterized by the presence of a rather small number of local natives and were filled up by natives of the inner regions of the Russian SFSR, as were the forces located in the zone of military operations" (RGVA 40442/3/2/25). Altogether, in the Kharkiv and Kyiv military districts and the Red Army field units stationed in Ukraine at that time, there were 995,882 Great Russians, 130,914 Ukrainians, 28,229 Jews, 41,850 Tatars and others (RGVA $40442 / 2 / 3 / 43)$. The census data reveal as erroneous the assumption by the British historian Geoffrey Hosking that significant masses of Ukrainians supported Soviet rule (54).

In accord with the report of the Ukrainian Economic Consultation to the RSFSR Council on Labour and Defence, in 1920-21 a plan for grain collections in the amount of 160 million puds was established for the Ukrainian SSR, which was later lowered to 105 million puds; 76.7 million puds were apparently delivered to the state (Narodnoe khoziaistvo 509, 512). Aside from grain, the allotment covered potatoes, oil seed, meat, fowl, eggs, and dairy products. The amount of the grain that was shipped out of Ukraine was not reported. From this same source we learn, however, that in 1921, 18,903 rail cars of grain left Ukraine for the RSFSR, 1,653 for the Caucasus, and 1,134 for the Crimea-altogether 21,690 (Narodnoe khoziaistvo 598). The report states that the famine in the Volga region of Russia, which began in 1921, "demanded that Ukraine render significant assistance" (Narodnoe khoziaistvo 607), and also that "crop failure in Ukraine was determined relatively late, when its manifestations in the form

\footnotetext{
${ }^{6}$ Letter of representatives of the Ukrainian Communist organization in the Moscow committee of the Russian Communist Party (Bolsheviks) to the Central Committee of the Russian Communist Party (Bolsheviks) and personally to Lenin with an analysis and evaluation of the Communist Party's policy in Ukraine in 1919. 12 Nov. 1919. TsDAHO 57/6/15/1-17. Cited in Iefimenko 192.
} 
of famine took on the dimensions of a great national calamity" (Narodnoe khoziaistvo 659).

In considering the circumstances that enabled the Bolsheviks to reincarnate the imperial project, Kappeler noted that " $[t]$ he gathering of the lands of the tsarist empire by the Bolsheviks was carried out with the welltried methods of the carrot and the stick and divide et impera (that is, by exploiting social and ethnic antagonisms)" (Rosiia 282). Contemporary scholars have also pointed out that in 1920 the Bolsheviks' communist slogans were closely bound up with Russian imperial rhetoric. "The territory the Red Army was fighting to reclaim," writes Hosking in this connection, "was, with a few modifications, the former Russian Empire, so that oldfashioned Russian patriotism was an acceptable motive for service within it" (54). The Bolsheviks' imperial expansionist rhetoric was also aimed the Russians in the Red Army. A brochure published in 1919 for dissemination among the Red forces entitled Na iug! Na iug! (To the South! To the South!) explained to soldiers mobilized in the inner gubernias of the Russian SFSR the necessity of reclaiming the "national borderlands" for the control and exploitation of resources - grain, coal, etc.-needed by the north. "It turns out that our chief resources are located at the borders," it states, adding "and in the centre we have almost nothing. The centre cannot survive without the peripheries" (Baratov 8).

The question of how such slogans could have contributed to the development of an imperial mentality among Russian Red Army peasant soldiers, as well as the question of the perception in Ukraine itself of the offensive of the Russian SFSR Red Army as an imperial intervention, remain to be studied. Some documents, different in origin, testify to the manifestation of both imperial and anti-colonial attitudes.

UKRAINE IN THE SOVIET UNION AS THE BREADBASKET OF THE USSR: IMPOSITION OF Grain Specialization as an Indicator of DEPENDENCE AND A PREREQUisite of FAMINE

One can confidently assert, ex post facto, as a glaring example of Soviet imperial-colonial rule, the cotton "specialization" imposed by Moscow on the Central Asian republics in the 1920s and the refusal to diversify agricultural production, which led to a large-scale ecological catastrophe and the devastation of the Aral Sea. A consensus seems to have been reached in recent scholarly historiography characterizing Soviet policy in Central Asia as imperial and colonial (Cameron; Edgar; Khalid; Kindler; Sahni; Slezkine). The Ukrainian situation in the 1920 s and 1930 s was to a certain extent analogous. For Ukraine, it was "grain specialization" imposed by the Union centre, the purpose of which was provision of grain resources to the growing 
industrial regions of the north and for the procurement of currency for industrial modernization.

During the years of war and revolution, Ukraine lost its position as a leading grain exporter. By 1926-27, as a republic of the USSR, it had reached only 25.6 percent of its pre-war grain exports, 55 percent of its exports of eggs, and 38 percent of its sugar exports. ${ }^{7}$ Although exports abroad had fallen, from the beginning of the 1920s a clear tendency was noticeable on the part of Moscow to reorient Ukraine toward grain deliveries to internal USSR markets, chiefly to the industrial regions of the Russian SFSR that were experiencing rapid urban growth. In 1923-24, 83.4 million puds of the chief grain crops were shipped from the Ukrainian SSR to internal USSR markets, while 85.1 million puds were exported; in 1925-26, the figures were 89.6 million and 42 million puds, respectively; in 1926-27, 84.6 and 56.2 million puds (Al'terman 40-41). The largest shipments out of Ukraine were of wheat: in 1926-27 they constituted over 50 percent of the grain sent to the union republics, and 40 percent of grain exports (Al'terman 43).

This role of exporter and "breadbasket of the USSR" created stresses for Soviet Ukraine. In fulfilling the centre's shipment orders, the Ukrainian SSR, even in years of good harvests, was left without evident transitional grain reserves, which undermined its grain market (TsDAVO 3/1/5038/8). A survey carried out by the Ukrainian SSR Central Statistical Administration in the spring of 1925 showed that two thirds (68.1 percent) of all peasant households in the forest-steppe region had sown enough grain only for their own needs. Even in the most commercially productive region of the Ukrainian SSR, the steppe, such households constituted just over a quarter (27.3 percent) (Al'terman 27). Thus, a significant portion of Ukrainian peasant households were able to sustain only themselves, with very modest amounts left for the market.

The causes of the weakness of the Ukrainian grain economy can in part be found in the radical social changes resulting from the 1917 Bolshevik revolution: the dissipation and destruction of effectively functioning landed estates and the redistribution of their land among five million peasant households. Ongoing crop failures, caused by a combination of unfavourable natural-climatic conditions and the policies of the communist regime, also shook the Ukrainian grain economy. Large-scale crop failure and famine afflicted Ukraine in 1921-23. The crop failure and famine of 1924-25, the circumstances of which are yet to be researched, dealt a considerable blow to agriculture in the Ukrainian SSR. Agrarian over-population, too, remained a problem for Ukraine: according to some prognoses, by the end of the first

\footnotetext{
${ }^{7}$ Chernov. On the specifics of USSR foreign trade, see also Frumkin.
} 
Five-Year Plan there could have been a "surplus population of nearly 8.5 million" (Popov).

All this undoubtedly actualized the problem of reorganizing and intensifying agricultural production in Ukraine. Ukrainian economists, agronomists, and national-communist politicians viewed this problem in the context of the reconstruction and modernization of the Ukrainian SSR as an integral economic unit where the disproportions in economic development, deemed to be a "colonial legacy," would be addressed. The official position of Moscow was in direct opposition, proceeding from the intention to create a strictly hierarchical economic space with a single centre and zones of agricultural production as well as raw material extraction for industry, to be demarcated by the centre. Thus, despite the status of the USSR as a federation of republics with equal rights, the traditional view of Ukraine from the times of the Russian Empire as simply the south of Russia, the resources of which were to be exploited according to all-Union interests, determined by the centre's Gosplan, prevailed (Hirsch 98).

The perpetuation of the traditional imperial view of Ukraine as the "south of Russia" and a supplier of raw materials caused tensions in relations between Moscow and Kharkiv (which was since 1923 the capital of the Ukrainian SSR), especially in the second half of the 1920s during discussions and confirmation of the first Five-Year Plan. An analogous situation arose in the other former Russian "national borderlands." According to Francine Hirsch, "[t]he tension between the economic and the ethnographic paradigms for regionalization would remain at the heart of Soviet statebuilding throughout the next decade" (98).

In Ukraine in the 1920s, scientists from various institutions and officials of Derzhplan (the State Planning Committee) of the Ukrainian SSR participated in discussions of Ukraine's economic specialization and ways to improve the effectiveness of the republic's agricultural sector. Proceeding from rational assumptions about a Ukrainian economic organism formed by natural-climatological and historical factors, Ukrainian economists proposed that the Ukrainian SSR should, already during the first Five-Year Plan, (a) reorient itself to the development of technical crops as a raw materials base for the republic's economy, (b) intensify the commodification of livestock management, (c) take measures to improve technical support of agricultural production; and (d) significantly lessen the focus on grain, the vulnerability of which, due to frequent crop failures and low marketability, was evident (Al'terman 101-10; Soloveichyk; Kononenko 184).

Calls for the "decolonization" of Ukraine's agricultural production were closely correlated with proposals for the reconstruction and development of industry. Ukrainian economists and planners thus disagreed with projects outlined in the Five-Year Plan proposed by all-Union authorities, which, in their opinion, would limit and slow Ukraine's industrial development, and 
perpetuate its role as a supplier of industrial raw materials for the north. These projects were also viewed as irrational and economically problematic and were thought to create disproportions in the development of the Ukrainian economy in favour of the Russian SFSR.

At the beginning of 1928, an article by the economist Mykhailo Volobuiev entitled "Do problemy ukrains'koi ekonomiky" ("On the Problem of the Ukrainian Economy") was published in two issues of the political and theoretical journal Bil'shovyk Ukrainy (Bolshevik of Ukraine), in which the author presented ideas, facts, proposals, and also complaints of Ukrainian experts. Volobuiev described Ukraine as a former Russian "colony of the European type" and accused the Soviet government of continuing the colonial practice of exploiting Ukrainian economic resources. Volobuiev's basic thesis was that "the essence of the effects of colonial dependence for a colony of the 'European type' is chiefly the denial of the development of its productive powers for the benefit of the metropolitan economy" ("Do problemy" 167). The article presented the "Moscow" and "Kharkiv" projects as in competition. Given the formality of the federative status of the republics and their full subordination to Moscow, Kharkiv had no chance of success.

"Volobuievism" was soon denounced, along with "Khvyl'ovism" and "Shums'kyism."8 At the end of November 1928, Volobuiev published a letter of recantation in the same periodical Bil'shovyk Ukrainy ("Lyst"). A few days later, on 26 November 1928, the Fourth All-Union Consultation of People's Land Commissars was held in the Ukrainian capital, at which the representative of the USSR State Planning Committee Moisei Vol'f defined the position of the Union centre: "In the historical perspective, we think that Ukraine should, for a prolonged time, even in conditions of increased crop yield, remain a country that exports grain to the North, and if the North does not need it, then abroad? I think that for the next five to ten years that is precisely how it will be" (TsDAV0 1/4/635/6 verso). This strategy for the next decade was confirmed in the consultative body's resolution, by which the USSR's State Planning Committee Gosplan was designated the right to determine the "grain balance of individual districts" and the list of districts that "should be ensured grain supplies by way of shipments" (TsDAVO $1 / 4 / 635 / 52$ verso).

On 7-14 March 1929, at the Fifth Congress of State Planning Committee Presidiums in Moscow, Vol'f-now the chief of the agricultural section of the USSR Gosplan-presented a plan for the agricultural subdivision of the USSR

\footnotetext{
8 The three "isms" associated with the economist Volobuiev, the national communist and advocate of Ukrainization Oleksandr Shums'kyi, and the writer Mykola Kvyl'ovyi are discussed in three chapters of James Mace's Communism and the Dilemmas of National Liberation (86-190). On the "Shums'kyi affair" and on Kvyl'ovyi, see also Terry Martin's The Affirmative Action Empire (96-98, 212-28).
} 
into seven groups. In keeping with the strategy of creating a single economic space, the Ukrainian SSR was not regarded as an integral whole; its lands were divided between the third group (the Central Black Earth Region and Ukraine's Forest-Steppe Region) and the fourth (the Ukrainian Steppe, North Caucasus, and Crimea). The principal tasks for the latter group were determined to be the reconstruction of grain agriculture, increased grain exports (75 percent of total grain exports), and grain deliveries to internal USSR markets - to Belarus, the Transcaucasus, and the Central Industrial Region. It was foreseen that the relative weight of these districts in producing commercial grain could be lowered at the end of the First FiveYear Plan from 74 percent to 53 percent because of an anticipated rise in production in the East (Problemy 291-92).

Effective imperial leadership depends on the participation of local and regional elites. In the Ukrainian SSR of that time, the administrative elites were in part local cadres, but Moscow sent its emissaries, entirely in keeping with imperial tradition, to the most important posts, which in Ukraine was the position of the first secretary of the Communist Party (Bolsheviks) of Ukraine (CP(b)U). At the beginning of April 1929, at a plenum of the Central Committee of the CP(b)U in Kharkiv, Stanislav Kosior, recently deputized by Moscow as the first secretary in Ukraine, harshly criticized the advocates of diversification of agricultural production-those who sought to reduce the volume of grain production: "I think that the grain question," stressed Ukraine's chief communist, "is absolutely the fundamental and chief question for us not only in the next five years, but in the next ten. We are the basic grain district, and for us, the issue of the grain problem is the central issue" (TsDAHO 1/1/324/108-109; emphasis added).

A resolution of the Party Central Committee plenum stated that "For a long time to come, Ukraine will be the most important base for meeting the internal food supply needs of the USSR, as well as a supplier of grain for export" (TsDAHO 1/1/322/87). The same was stated in the resolution of the Eleventh All-Ukrainian Congress of Soviets on the Five-Year Plan for the development of the republic's national economy. The "central and most important task" for Ukraine was to be the development of grain crops, chiefly for food, and among the latter, rye and wheat were the most valuable ("Na zahal'nu dopovid'"; Zbirnyk). Thus, the Union centre, through indirect administration of the Ukrainian republic, imposed grain specialization as the Ukrainian SSR's priority, with an emphasis on supplying grain for export and to internal USSR markets for five to ten years, which included the years of mass starvation-the Holodomor.

Those who actively opposed the centre's plans were punished or repressed. Many non-party specialists-economists, historians, agronomists - had already been repressed in 1930 in the affair of the "counter-revolutionary organization" sabotaging agriculture of the 
Ukrainian SSR" (Marochko; Sprava). Arrests continued as the Holodomor gained momentum in 1933, including of those who had argued that Ukraine's narrow grain specialization was a sign of its colonial status.

In the criminal case file of the convicted vice-president of the AllUkrainian Academy of Agricultural Sciences Andrii Slipans'kyi (1896-1942), we find admissions, beaten out of him by his interrogators in private conversations, that the agronomist had spoken of the need "to destroy the colonial status of Ukraine in the USSR, and to regulate the situation of Ukraine in the USSR in accordance with its economic resources." $\mathrm{He}$ admitted that "with harmful intent," he had advocated the development of pig-farming in the steppe "in order to curtail the sowing of grain there and by that means to reduce the significance of Ukraine as a grain-producing region." ${ }^{\prime \prime}$ Finally, in interrogations on 17 and 20 August 1933, Slipans'kyi acknowledged his "guilt," saying that "he had created a harmful plan of specialization of Ukraine's agriculture in which a policy of intensified development of technical crops was undertaken to the detriment of grain" (DAKhO P-6452/3/1555/57, 63).

This same theme was evident in a campaign launched in the press to defame "exposed enemies." One of the articles appearing in the periodical Bil'shovyk Ukrainy stated that " $[\mathrm{t}]$ he wrecker Slipans'kyi advises us to direct reconstructive reforms in the steppe region of Ukraine towards the decisive elimination of grain farming and the maximum development of technical crops and the feed base for livestock ...." The same article states:

By means of these destructive aims, Slipans'kyi opposed the general national-economic tasks of the Union with his policy favouring the "independence of Ukraine" (one of the most important grain-producing regions in the USSR), and sought to detach the economic development of the Ukrainian SSR from the economy of the entire Union. At the same time, by way of these aims Slipans'kyi seeks to transfer the orientation of Ukraine's agriculture toward the Western capitalist countries, and especially Germany. (Borodaev et al. 119)

The danger inherent for Ukraine in its grain specialization became clearer upon the confirmation by the USSR government in April 1929 (Izvestiia TsIK) and the Fifth All-Union Congress of Soviets in May 192910 of an optimal plan for the first Five-Year Plan. It was based on extraordinarily high planning targets, especially regarding increases in crop yield. According to the plan, the average crop yield was to increase by 35 percent by the end

\footnotetext{
${ }_{9}^{9}$ DAKhO P-6452/3/od. b. 1556/44, 64. I am grateful to the Kharkiv historian Ihor Shuis'kyi for his assistance in obtaining materials from the criminal case file of Slipans'kyi.

10 O piatiletnem plane. See also Sobranie; S'ezdy Sovetov 155-61.
} 
of the Five-Year Plan, while for all types of peasant households in Ukraine it was to increase by 36.6 percent ("Na zahal'nu dopovid'"; Zbirnyk). In order to carry out this unrealistic plan, Ukrainian peasants would have had to ensure an annual increase in crop yields of 6.5 percent. For comparison: in the most favourable pre-war years, an annual increase never surpassed two percent. The measures to be taken to achieve such high crop yields, especially the collectivization of 30 percent and the conversion to cooperatives of at least 85 percent of peasant households, were manifestly inadequate and did not take into consideration the possibility of unfavourable natural-climatological conditions.

In the final version of the First Five-Year Plan announced in 1930, the strategy of treating the USSR as a single economic space was fixed. The territory of the USSR was divided into four production zones: industrial, agricultural, agro-industrial/industrial-agrarian, and forest. Ukraine was allocated partly to the first and partly to the second zone type. The plan declared the goal of raising the level of grain farming and turning Ukraine and the North Caucasus into "primarily zones for export" (Piatiletnii plan 63). It also confirmed "the supply of grain by Ukraine, the North Caucasus and the Trans-Volga region to the consumer zone of European Russia" "over the next eight-ten years" (Piatiletnii plan 23-24). By 1933, the crop yield in Ukraine for the eight chief grain cultures was to increase by 36.3 percent, and in the collective farms, by 53.6 percent (Piatiletnii plan 126-27).

The projected increases in expected crop yields found in the Five-Year Plan concealed no small threat to the Ukrainian peasants, as planned high crop yields foretold significant increases in grain procurements. In view of the increasingly clear tendency to "legalize" imperfect statistical methods for determining the size of the harvests, the indiscriminate seizure of grain resources from the Ukrainian peasants, even in conditions of their absence, became a predictable prospect. Together with the imposed grain specialization, with a distinct determination to exploit grain resources, these expected crop yields foreshadowed the disorganization of the Ukrainian grain market and elevated the risk of eventual famine.

INTRA-UNION GRAIN DELIVERIES FROM THE UKRAINIAN SSR IN 1927-28 AND 193233: A BLIND SPOT IN RESEARCH ON STALINIST ColLECTIVIZATION AND FAMINE

Did Excessive Exploitation of Ukrainian Grain Resources Take Place, and How Could This Have Affected the Onset of Famine?

In his landmark work Poverty and Famines, economist Amartya Sen proposed that the onset of famine is connected to the deprivation of economic rights and to unjust distribution. Through the example of the actions of the British colonial administration in Bengal, India in 1943, Sen 
demonstrated that it is not the lack of food as such but the inability to obtain it that causes famine.

Applying Sen's approach to the situation in the USSR at the end of the 1920s and the beginning of the 1930s, one can see the deliberate actions of the communist government directed toward depriving an entire social stratum, the agriculturalists, of their economic entitlement. The forced liquidation of private farmsteads, the deportation of the so-called kulaks, the creation of collective farms, the setting of extraordinarily low wages for the labour of the collective farmers (in "labour days"11), high targets for grain deliveries to the state, in effect its forcible seizure-these caused the phenomenon that Graziosi refers to as the all-Union famine of 1931-33.

Sen's principle of economic entitlement applies to relations between the USSR centre and the national peripheries, especially Ukraine. De jure a republic with equal rights within the federative USSR and its own government and declared rights, de facto the Ukrainian SSR was prevented from managing its own grain resources, a result not only of the communist but also the imperial nature of the USSR, where Moscow was the metropolia, ruling over Soviet Ukraine as a subordinate periphery. It was the intentional actions of the central government in establishing total control over the republic's grain market that led most directly to the deprivation of economic entitlement in Soviet Ukraine.

In this context, the liquidation in 1928 of Ukrkhlib (Ukrainian Bread), the powerful grain procurement and flour milling trust of the Ukrainian republic, must be mentioned. Created by a resolution of the All-Ukrainian Central Executive Committee of 1 September 1926, Ukrkhlib played a key role in grain procurement and in supplying the Ukrainian population, as it was responsible for intra-Union deliveries and export operations. At the beginning of 1928, the Ukrainian trust had at its disposition ninety-four enterprises, at least fifty mills, and a similar number of grain collection stations (TsDAVO 778/1/280/219), with profits in 1926-27 of 3,278,548 rubles and 33 kopecks (TsDAVO 778/1/280/425). Moscow terminated Ukrkhlib's activity, and its shares were confiscated by Soiuzkhleb (Union Bread), thus depriving the Ukrainian SSR not only of a major portion of its own capital but also of critical levers of influence on its own grain market.

The process of total subordination of the Ukrainian grain market to Moscow was completed by the beginning of the 1930s. On the eve of and during the Holodomor, the incredibly high grain procurement quotas for the Ukrainian SSR, the reduced and extremely insufficient plans and volumes of food supply deliveries to the population, the plans and volume of exports,

11 Payments for labour performed by collective farm workers on collective farms (mostly in-kind payments), were calculated according to a formula-given the name "labour days"-which was based on the time spent working and the type of work. 
and also the plans and volume of shipment of Ukrainian grain to intra-Union markets-all was decided not in Kharkiv, but in Moscow. The peripheral elites in the Ukrainian SSR, some sent from Moscow and some of local origin, lacked real influence over the situation and essentially served as instruments of indirect rule or administration.

Given what we know about the grain specialization imposed by the Union centre on the Ukrainian SSR (at a minimum during the first Five-Year Plans) and about the declared aims of intensified shipment of grain resources out of Ukraine, the question logically arises: can one speak in terms of the economic exploitation of Ukraine through control of its grain resources to the benefit of the ruling metropolia, and if so, how did this impact the onset of the Ukrainian famine of 1928-29 and the Holodomor of 1932-33?

To understand how famine arose in the Ukrainian SSR in 1927-28 and 1932-33, the volume of grain removed in the course of state grain procurements is of prime significance. Contemporary research confirms the substantial dimensions and the consistently high proportion of Ukrainian grain in deliveries for central government's stores or funds of grain. In 192728 in particular, 260.2 million puds of grain were procured from the republic, which constituted 40 percent of the procurement total for the USSR. This reached 46 percent in May ("Na Ukraini"). In 1930-31, after the gathering of the first collective farm harvest, 468.5 million puds of grain were procured from Ukraine-39 percent of the all-Union procurement, and in 1931-32, 442.7 million puds, or 31.7 percent (Ezhegodnik 7). Grain procurement from the Ukrainian SSR continued both in the famine years 1928-29 (124.6 million puds of grain, or 18.9 percent of all-Union grain procurement) (TsDAVO 3/1/6433/104, 1/5/472/1), and during the Holodomor of 193233 (258.4-262.2 million puds, or 22.9-23.1 percent of all grain deliveries to the state) (Ezhegodnik 19). Altogether, over the course of six years, at least 1,833 million puds of grain were procured from Ukraine (29.8 percent of the all-Union amount procured).

The central government directed a significant portion of the grain procured in the Ukrainian SSR for export to finance ambitious plans for military-industrial modernization. In 1927-28, the amount of Ukrainian grain exported abroad was still rather modest-only 20 million puds (TsDAVO 23/4/164/26-27); in 1930-31 it had risen by a factor of five, reaching 103.7 million puds (30.3 percent of the USSR export of 341.8 million puds) (Kondrashin 97). "Force the export of grain to the fullest. That is the key now. If we export grain, we will have credits," wrote Stalin in a 
letter to Molotov on August 6, 1930, during the gathering of the first collective farm harvest (Kosheleva et al. 147). ${ }^{12}$

As is evident from the statistical annual devoted to grain, Ezhegodnik khlebooborota, in 1931-32 the Ukrainian portion of the grain exported constituted 151.4 million puds, which was 51.8 percent of the total USSR export of 292.2 million puds (Ezhegodnik 65). In 1932-33, during the Holodomor, 45.6 million puds of grain from the Ukrainian SSR went for export (46.6 percent of the USSR shipments abroad of 98.0 million puds) (Ezhegodnik 67). One can see that the volume of exported Ukrainian grain leading up to and during the period of massive famine and human mortality was enormous.

In the years 1927-28 and 1932-33, Ukrainian grain was shipped not only abroad but also to internal USSR markets. Despite the considerable Western, Ukrainian, and Russian historiography on collectivization and famine in the early 1930s, the subject of internal USSR grain shipments, particularly the deliveries of Ukrainian grain to the industrial districts of the Russian SFSR and other Union republics, has yet to be examined. This may be due in part to an unconscious tendency to avoid issues that cast doubt on the sincerity of the anti-imperial and anti-colonial slogans loudly declared by the USSR. In the USSR itself, the practice of censoring information about the volume and characteristics of internal USSR grain shipments emerged at the end of the 1920s. One indication was the cessation of hitherto regular publications with accompanying diagrams on the pages of the specialized periodical Statisticheskoe obozrenie (Statistical Review). As supported by descriptions I have studied of holdings of the Central State Archive of Higher Organs of Government and Administration (TsDAVO) of Ukraine, there are reasons to suspect that archival documents that could shed light on this topic were destroyed or transferred to Moscow in the postwar years, in the course of periodic inspections and "purges" of the Ukrainian archives.

These observations, however, pertain to the situation for the years 1932-33. Fortunately, archival documents related to the intra-Union grain shipments on the eve of and during the Ukrainian famine of 1928-29 have been preserved fairly well. Their diligent study opens significant perspectives for a better understanding of the mechanisms that triggered the onset of the Holodomor. A considerable increase, in accordance with directives from Moscow, in the volume of shipments of Ukrainian grain to the north began in the second half of 1926-27, during an intensification of the "grain crisis" and crop failures in the grain-producing regions of the USSR. In the summer of 1927, after a prolonged drought, a crop failure took place in Ukraine, which according to the report of the People's Commissariat

12 See also Kondrashin 96, 280. 
of Land of the Ukrainian SSR "On the Crop Failure and Measures for the Struggle with Its Consequences," engulfed close to eighty thousand farms in the Kherson, Mykolaiv, Odesa, Mariupol, Melitopol, and Staline regions (TsDAVO 582/1/2567/232-233).

Nevertheless, during the grain procurement campaign of 1927-28, the USSR centre chose the path of intensifying the exploitation of Ukrainian grain resources. During a meeting in Kharkiv, the representative of the USSR People's Commissariat of Foreign and Domestic Trade Izrail' Veitser, having arrived from Moscow, declared,

We are not shutting our eyes to all the difficulties that Ukraine faces .... We are aware of all these difficulties and we do not want to conceal or minimize their significance. All the same, we face the following task: we have to remove as much grain as possible from Ukraine; this is the goal we have set ourselves. (TsDAVO 337/1/5762/110-111).

At this point Kharkiv was still trying to challenge Moscow and demanded a reduction of shipment orders. On 22 July 1927, the Ukrainian Economic Consultation sent the USSR Council on Labour and Defence a report regarding Ukraine's limited ability to supply grain, directly stating that "the chief cause of the aggravation of the situation in Ukraine's grain market is the increased shipment of grain to the northern markets" (TsDAVO $337 / 1 / 5762 / 139) .{ }^{13}$

In the spring of 1928, as summer neared, the situation in the Ukrainian grain market became acute, and it was understood that the republic was facing large-scale crop failure. Famine ensued in a number of districts of the Ukrainian SSR. Nevertheless, Moscow continued to demand grain shipments. Realizing the obvious deficit of resources in the republic, the central government invented the tactic of "lending" grain to Ukraine from the State Fund, to which Ukraine had previously contributed to fulfill its shipping orders. The "grain debts" it thus accumulated for deliveries of grain to the state reserve funds were not written off, but only deferred. For example, in mid-March 1928 the Collegium of the USSR People's Commissariat of Foreign and Domestic Trade permitted the Ukrainian SSR to defer 800,000 puds of wheat planned for shipment out of the republic to the first ten days of April (TsDAVO 423/4/342/66; 423/5/15/171). On 24 April 1928, during a meeting in Moscow on grain procurement presided over by Viacheslav Molotov, the Ukrainian representatives Vlas Chubar and Mikhail Chernov were informed of the deferment of this debt and were offered a loan from

\footnotetext{
13 I have discovered similar petitions, mostly in "special files," dated 21 February; 2, 9, 27, and 30 March; 2, 7, 9, 12, and 27 April; 11 and 18 May; and others (TsDAHO $1 / 6 / 142 / 48-49,60,68,75,81-82,96,101-102,105-106 ; 1 / 20 / 2769 / 1-2$; 1/20/2771/52; 1/20/2772/47-48; 337/1/6414/47; 539/6/7/26; et al.).
} 
the State Fund of 150,000 to 200,000 puds of wheat seed for the fulfillment of the shipment orders in May (TsDAHO 1/20/2769/2). On 4 May 1928, the Collegium of the USSR People's Commissariat of Trade confirmed the May plan for the Ukrainian SSR to ship out of Ukraine 4.2 million puds of grain. The plan provided for the deferment of 800,000 puds of "owed" grain as well as for new "loans": 400,000 puds of wheat seed to be shipped to Central Asia, Tambov, and the Central Black-Earth Region, and another 160,000 puds "for shipment to the north per orders of the USSR People's Commissariat of Trade" (TsDAVO 423/4/340/95). The next day, the Collegium of the USSR People's Commissariat of Trade let Ukraine borrow 850,000 puds of wheat from the State Fund in order to carry out the shipment plan (TsDAVO 423/4/340/88-89).

It was only on 26 May 1928, that, by a decision of the All-Union Communist Party Central Committee Politburo, the shipment of wheat and rye out of the Ukrainian SSR was officially stopped (up to 1 August 1928). The Commission for the organization of grain supply to the republic, created on 29 May 1928 by the Ukrainian Economic Consultation, issued a resolution instructing the Ukrainian SSR People's Commissariat of Trade to select, in June, fall-sown wheat from the State and Special Funds for distribution within the republic. However, on 30 May 1928, the Collegium of the USSR People's Commissariat of Trade formally transferred jurisdiction over Ukrainian grain to Soiuzkhleb and ordered it to ship all grain reserves out of Ukraine during the month of June, so that they should arrive as reserves at the bases of the USSR People's Commissariat of Trade. In the end, 127.7 million puds of grain, including 118.7 million puds of rye and wheat, were shipped out of Ukraine in 1927-28 to intra-Union markets, chiefly to industrial districts of the Russian SFSR (TsDAVO 1/1/308/11 verso).

This rather detailed description of the relations between Moscow and Kharkiv on issues of grain delivery at a time when Stalin's military-industrial modernization was accelerating, illustrates the inequality of relations and the subordination of the Ukrainian peripheral elite to the central government. The exploitation of grain resources by order of the USSR government, their shipment beyond the borders of Ukraine, the assertion of control over Ukrainian grain resources, and the deprivation of the Ukrainian government of evident liquid resources were the essential factors in the destabilization of the Ukrainian grain market and contributed to the onset of the Ukrainian famine of 1928-29, which took place against the background of a large-scale crop failure.

The question arises whether Ukrainian grain was being supplied to the intra-Union markets as well as for export, and if so, what if any role did it play in the onset of the Holodomor of 1932-33? This topic requires careful research that would greatly benefit from examination of a significant body of documents, in particular, from the archive of the president of the Russian 
Federation, which are not fully accessible to scholars. However, the amount of Ukrainian grain that might have been shipped to internal USSR markets in 1931-32 and 1932-33 can be arrived at on the basis of an analysis of statistical materials in the Ezhegodnik khlebooborota published in 1934. In 1931-32, 442.7 million puds of grain were procured in the Ukrainian SSR as a whole; 151.4 million puds were removed for export, while 148.6 million puds were allocated for internal needs of the republic (food supplies, seed, industrial needs, and forage, not counting allocations for the army, or bran). Accordingly, 142.7 million puds hypothetically could have been directed to supplying the army and for satisfying the internal needs of the rest of the USSR. We can make analogous calculations regarding 1932-33: out of 258.4 million puds of grain procured, 45.6 million were exported, 162.6 million went for the republic's internal needs, and 50.2 million puds of grain could have constituted the remainder for supplying the army, shipment to other republics, etc. (Ezhegodnik 7, 19, 65, 67, 81, 131). In sum, for two years, 192.9 million puds is a fairly significant amount of grain, even if one subtracts from it annually 5-6 million puds of grain for the army.

Documents preserved in the Ukrainian archives suggest that even in the famine conditions of 1932-33, the shipment of grain out of Ukraine to other regions of the USSR may have continued. According to orders of the USSR centre, beginning with 1 October 1932, Zahotzerno and Souizboroshno were to ship 31.7 million puds of wheat and rye to Moscow, Leningrad, the Central Black Earth Region, Crimea, Belarus, and the Transcaucasia. This grain was to be sent for export, and internally to the GULAG, to Torgsin, and to replenish the State and Reserve Funds in Moscow, Leningrad, the Northern and Western regions, Belarus, and so on (Sovetskaia derevnia 880-81; "Sovershenno sekretno"196-97, 246-47).

Worth noting here is that grain was not the only "article" in the planned deliveries of the countryside to the state. In 1927-28 and 1932-33, there was massive procurement of "secondary agricultural production" from Ukraine and shipment to other regions of the USSR and for export. This included meat, poultry, butter, eggs, honey, nuts, fruit, vegetables, and so on. The structure, dimensions, and results of the seizure of "secondary products" from the Ukrainian village remain unstudied by scholars. We do know that in the year of the Ukrainian famine of 1928-29, there were 2,020 freight-cars of eggs, 164,000 puds of butter, 305,800 puds of bacon, 747,400 puds of meat products, 2,986,000 puds of potatoes, 9,389 puds of mushrooms, 4,231 puds of honey, 2 million 549.8 thousand rubles' worth of sunflower oil, 94.2 thousand rubles' worth of cow and sheep's milk cheese, 89.5 thousand rubles' worth of conserves, 2 million 518.1 thousand rubles' worth of poultry, 7.6 million puds of sugar, 248.1 thousand rubles' worth of fresh fruit, 131.8 thousand rubles' worth of pastry, etc., shipped from Ukraine for export (TsDAVO 3/1/6041/112-114). 
Finally, according to information from the Procurement Committee, in 1930-31 the Ukrainian SSR provided two-thirds of all the grain contributed to the state reserves (Vasyl'iev 241). The republic's share in the replenishment of the Reserve and Mobilization grain funds could have been significant in 1931-32 as well. From October 1931, both funds were under the authority of the Reserves Committee of the USSR Council on Labour and Defence. Where these funds were located, whether Ukrainian grain was shipped to them, and in what amounts, whether it was expended and where it was directed during the Holodomor-all of these remain open questions.

ALL-UNION AID DURING THE UKRAINIAN FAMINE OF 1928-29 AND THE HOLODOMOR of 1932-33: AN ELEMENT IN THE STRATEGY OF EXPLOITATION OF RESOURCES ${ }^{14}$

During the crop failure and famine of 1928-29, the central government did render aid to the Ukrainian SSR. Based on this fact, the American scholar Mark Tauger, in an article on the Ukrainian state commission for rendering aid to the victims of the crop failure, came to the following unambiguousconclusion: "in terms of food supplies, Ukraine in 1928-1929 was not in the extractive-colonial relationship with Russia that Volobuiev described at the time. As already noted, Ukraine received more in food supplies during this famine crisis than it exported to other republics" (168). Tauger also sees in this episode "another side of the Soviet regime, one concerned with alleviating suffering rather than creating it," and among other examples in support of his thesis cites a story of Moscow's speedy reaction to the petition of the Ukrainian side for aid to starving children (168). "Sovnarkom SSSR," writes Tauger, "acted on this request rapidly, authorizing Ukraine on 5 February to use an additional 1,316,500 rubles to feed children in the crop-failure districts" (159).

Tauger is mistaken. Attentive study of a broader range of archival sources reveals Soviet aid to Ukraine under famine conditions in 1928-29 to have been a typical imperial practice. The centre's exploitation of the territory under its control continued-merciless and deaf to the sufferings of the population, including children-even during cataclysms and mass hunger. In 1928-29, Union-republic co-operation in the development of plans for state assistance to Ukraine, suffering from crop failure, took place in conditions of clear dominance by the All-Union centre, and was determined by the Stalin group in the Party leadership, whose primary goals were to accelerate military-industrial modernization. It is in this context that

\footnotetext{
${ }^{14}$ Some of the material in this section is discussed in my study Holod 1928-1929 rr. $u$ radians'kii Ukraini (215-24). See also my criticism of Tauger in the same study (710).
} 
the strategy imposed by Moscow on Kharkiv must be understood-of the Ukrainian SSR surviving in conditions of crop failure and famine at the expense of its own resources. The USSR's People's Commissar of Trade Anastas Mikoian openly announced this strategy at the November 1928 Communist Party of Ukraine Central Committee plenum, whose participants, as the documents show, expected information on the rendering of All-Union aid. Mikoian instead declared: "I have said-procure bread and eat it!" (TsDAHO 1/1/306/63). Another remark by Mikoian indicated that Moscow was fully aware of the possibility that famine could arise in Ukraine: "If you cannot feed yourself in November, then what will happen in March, April, June? I can imagine what will happen in Ukraine in those months" (TsDAHO $1 / 1 / 306 / 53)$.

Despite the modest petitions of the Ukrainian side for assistance to the republic in 1928-29, the USSR Council of People's Commissars, by its resolution of 4 September 1928, reduced delivery of the most important items by half, including those earmarked for the feeding of children (TsDAVO $1 / 4 / 72 / 23$ ). Further, during the budgeting process, it substantially reduced the volume of aid, essentially transferring a part of the financial burden of assistance to the republic itself. Chubar openly stated this at the Party Central Committee plenum on 19 November 1928, pointing out that while the All-Union organs had inserted certain amounts for aid to Ukraine in the budget, they simultaneously reduced expenditures by practically the same amount: "It turns out that the lion's share of these expenditures are also the Ukrainian expenditures that have been eliminated," he concluded (Kak lomali NEP 173). Thus, the expenditure portion of the Ukrainian SSR draft budget for 1928-29 in the amount of 415.8 million rubles, which was characterized by the Ukrainian side as a "miserly minimum," was approved by a resolution of the USSR Central Executive Committee, but for an even lesser amount of 388.3 million rubles. The republic's actual budget expenditures though came to 403.9 million rubles (Kak lomali NEP 173). The deficit was covered indirectly from funds allocated in the budget as USSR assistance.

During the entire year of 1928-29, a hungry year for Ukraine, the centre continued with bureaucratic delays in financing assistance measures from the All-Union budget, and time and again resorted to resolving the issue "of additional aid" at the expense of Ukrainian resources. The issue of the designated 1,316,500 rubles for starving children mentioned by Tauger is a vivid example of this, which I explore in more detail.

The question of feeding children was not a straightforward matter. At the beginning of the 1928-29 period, the Ukrainian government determined the minimum number of children to be supported as 342,000; after the USSR Council of People's Commissars twice reduced the volume of aid, however, the number of children to whom aid was to be rendered was lowered to 
185,000 (TsDAVO 3/1/6414/196; 27/10/71). On 17 January 1929, at the request of the Ukrainian Red Cross, the Ukrainian government sent to Moscow a report "On the Issuance of Additional Funds for Aid to the Child Population in Districts of the Ukrainian SSR Suffering from Crop Failure," requesting an additional 1,573,000 rubles from the USSR's budget to increase the quantity and improve the quality of children's food allocations, and for aid to infants and pregnant women (TsDAVO 27/9/523/32). The document stated, "In view of the shortage of funding, this aid, from the point of view of its quality, represents the bare minimum and could be regarded only as limited support, and not as providing the needed food" (TsDAVO $27 / 9 / 523 / 29$ ).

In fact, at the beginning of February 1929, the USSR Council of People's Commissars adopted a decision to issue for the children of the crop-failure districts of Ukraine 1,316,500 rubles (TsDAVO 27/9/523/29), requiring, however, that the local budgets of Ukraine be the source of these funds, which in conditions of crop failure had been greatly reduced. The essence of this matter can only be understood by way of a deeper study of archival materials that reflect the history of the long-term standoff between the allUnion and republican governments concerning the creation of the State Grain Fund from local budgets.

In 1927-28, the government of the USSR decided to create a State Grain Fund from contributions of the local budgets of the republics. Of the 40 million rubles it planned to obtain in this way, 28.6 million were assigned to the Russian SFSR, 8.9 million to the Ukrainian SSR, 0.9 million to the Belarusian SSR, 0.6 million to the Transcaucasian SFSR, 0.8 million to the Uzbek SSR, and 0.2 million to the Tatar SSR (TsDAVO 3/1/5111/1, 6). The Ukrainian side repeatedly petitioned for a reduction of the republic's contribution to 7.2 million rubles, complaining about the injustice of a situation in which the central government compensated for the reduced contributions from four republics with weak local budgets at the expense of the Ukrainian SSR exclusively. At the same time, the budgets of 17 out of 41 Ukrainian districts also suffered deficits (TsDAV0 3/1/5111/12).

Despite this, by the end of July 1928, Ukraine had transferred 5.9 million rubles from its local budgets to the State Grain Fund (TsDAVO $3 / 1 / 5111 / 33$ ). In connection with the massive crop failure, on 26 July 1928, the Ukrainian government appealed to the USSR Council of People's Commissars to release the republic from the remainder of its payments in the amount of 2.9 million rubles. The Ukrainian side also pointed out that up to that point only 3 million rubles of the 28.6 million due from the local budgets of the Russian SFSR had been paid to the Fund (TsDAVO 3/1/5111/33). On 27 November 1928, the USSR People's Commissariat of Finance presented a report to the All-Union government from which it emerged that the Ukrainian SSR had already transferred 6,283,500 rubles to 
the State Grain Fund by 1 October, and that it was to pay the remaining 2,616,500 rubles by 1 April 1929 (TsDAV0 3/1/6079/22). The Ukrainian side protested. On 5 January 1929, the permanent representation of the Ukrainian SSR in Moscow submitted to the USSR Council on Labour and Defence a petition for the elimination of the debt based on the extraordinary situation that had arisen as a result of the crop failure, noting, "Any further removal of funds ... for the creation of a State Grain Fund in a Ukraine struck by catastrophe could create a disastrous situation for the local budget" (TsDAVO 3/1/6079/22).

On 8 January 1929, the USSR Council of People's Commissars issued a resolution reducing Ukraine's debt to the State Grain Fund to 1,316,500 rubles (TsDAVO 3/1/6079/13-14). At the beginning of February 1929, as a supplement to this resolution, the USSR Council of People's Commissars finally resolved "to release the Ukrainian SSR from the transfer of 1,316,500 rubles for the financing of the State Grain Fund, permitting it to use these funds for food supply assistance to children in crop failure districts of the Ukrainian SSR" (TsDAVO 3/1/6079/20). Thus Ukraine, having finally succeeded in securing the cancellation of its remaining debt to the State Grain Fund, turned out to be in debt to itself, or rather, to the starving children, whose feeding now came as an additional burden on local Ukrainian budgets that were already exhausted by the crop failure.

Yet this is still not the entire story of Soviet aid to children. From the summer of 1928, the Ukrainian government had persistently petitioned Moscow for permission to hold an all-Union lottery to collect 2.5 million rubles to support the children. After the approval of the 1,316,500 ruble reduction in financing the State Grain Fund, on 5 February 1929, the People's Commissariat of Finance sent a report to the USSR Council of People's Commissars proposing that it abstain from organizing a lottery, instead giving the Ukrainian SSR permission to withdraw 1,316,500 rubles from regional budgets, ${ }^{15}$ to which sum 1,000,000 rubles would be added from the V. Lenin Fund of the USSR Central Executive Committee (GARF 5446/17/144). The decision regarding local budgets had been approved a few days earlier, but judging from the financial reports of the Ukrainian SSR's government, money for aid to hungry children from the fund named after the proletarian leader never arrived (TsDAVO 27/10/49/19).

And yet, the payment of various sums out of the all-Union, republican, or local budgets for carrying out the assistance plan did not solve the problem inasmuch as only real provisions, forage and seed, and not rapidly devalued Soviet money, could assure support for the hungry. And there was not

15 The word "regional" used in the text refers to an administrative unit called an "okruha," equivalent in size to a small province. Soviet Ukraine was divided into 41 such units in 1925. 
enough of any of these in famine-stricken Ukraine. It would have been possible to improve the situation only by shipping in sufficient grainessentially, by returning to the Ukrainian peasants at least part of the emergency reserves that had been taken from them in 1927-28.

During the Ukrainian famine of 1928-29, the central government had agreed initially to ship 22.3 million puds of wheat and rye to the Ukrainian SSR, but in the spring of 1929 reconsidered on the pretext that the Ukrainian population had already on its own "by means of carts and sacks brought in 5.0 million puds from the Crimea, Northern Caucasus and other regions" (TsDAVO 337/1/5941/46). In the end, 12.722 million puds of wheat and rye were shipped into the republic-and if one counts other comestible crops, 13.686 million puds. At the same time, 10.008 million puds of grain and flour (rye and rye flour, wheat and wheat flour, barley and barley flour, corn and corn flour, beans, semolina, buckwheat and barley groats, millet, etc.) were shipped out of Ukraine. ${ }^{16}$

Altogether, according to information reported by the Ukrainian SSR People's Commissariat of Trade, during 1928-29, five million puds of grain were expended as food aid for the population of the crop-failure districts and the poorer peasants of other regions of Ukraine, half of which was provided by a 10 percent deduction from milling fees (TsDAVO 1/5/472/2). As evidenced by report materials of the Government Committee, the planned deliveries of provisions to crop-failure regions, which were significantly lower than actual needs, were not carried out fully: 84 percent of the flour for adults specified by the plan was delivered, 88.2 percent of that for children, and 53.2 percent and 51.3 percent of the potatoes for adults and children, respectively (TsDAVO 27/10/49/4, 8-9). Seed aid for the peasants during the autumn and spring sowing campaigns accounted for something over 30 million puds (TsDAVO 1/5/472/2), and 5.5 million puds of this was shipped in from other republics, chiefly from Russia, while the rest was ensured by forcible "mobilizations" of local resources; 9.384 million puds went for cattle feed, and 2.526 million puds for the needs of Ukrainian industry. Centralized bread deliveries to city-dwellers in the Ukrainian SSR in 1928-29 constituted 34.654 million puds (TsDAVO 337/1/6433/46). Traditionally, a certain amount of grain was expended on deliveries to units of the Ukrainian Military District. Thus, state expenditures of grains and flour in Ukraine in 1928-29 came to something over 81.5 million puds. In this regard, the share of USSR aid in these expenditures, according to my calculations and taking into account the practice of the compensatory

16 TsDAV0 337/1/6433/10; 1/5/36/6. The information that Tauger adduces from Ezhegodnik khlebooborota is somewhat different, but in general the tendencies are analogous to the documents of Ukrainian provenance presented here. 
removal of grain, constituted 3.7 percent (according to Ukrainian report data) or 11.5 percent (according to central Soviet data).

Indubitably, the grain imported as assistance to Ukraine from other republics, chiefly the Russian SFSR, mitigated the situation, but it did not compensate even minimally for the losses that Ukraine, already experiencing partial crop failure, had suffered in 1927-28 through the shipping out of a substantial portion of its emergency reserves. The central government's "compensatory practice" was denounced in a letter of 7 February 1929, to the USSR Council on Labour and Defence from the Ukrainian Economic Consultation, signed by Ukraine's head of government, Vlas Chubar. In essence, the shipping into Ukrainian territory of "Union aid" was accompanied by the simultaneous shipping out of practically the same amount of seed grain and forage (TsDAVO 423/5/798/151).

The strongest proof of the negative effects of the exploitation of Ukrainian resources in 1927-28 and of the insufficiency and ineffectiveness of the aid rendered by the centre in 1928-29 was the onset of famine and starvation. According to estimates, more than twenty thousand people may have died from hunger in 1928-29. Judging from special reports of the OGPU (Joint State Political Directorate, i.e., secret police), the situation was most acute in April and May of 1929 (Sovetskaia derevnia 880-81; "Sovershenno sekretno" 196-97, 246-47).

In the case of the Holodomor, scholars have examined the decisions of the central government aimed at rendering aid to the Ukrainian SSR in the winter and spring of 1933, as well as the dimensions of this aid. In their thorough monograph on Soviet agriculture in 1931-33, Robert Davies and Stephen Wheatcroft include a series of tables that provide us with the following information: in February to July 1933, the Ukrainian SSR received loans and assistance in the amounts of 19.8 million puds of seed, 10 million puds of provisions, 5 million puds of fodder-altogether up to 35 million puds (479-85).

Without a doubt, the provision of aid saved lives. Nevertheless, knowing the causes of the Ukrainian famine of 1928-29 and Moscow's utilization of assistance as another element of exploitation-a strategy that used the resources of Ukraine for its own rescue-many questions arise. These include the possible cause-and-effect connection between the Holodomor and the massive procurement and shipping of Ukrainian grain for export and to the other union republics; the deliveries of Ukrainian grain to state grain reserves in 1931-32 and 1932-33; the actual sources of USSR assistance given Ukraine; and the possible application by the central government, as during the Ukrainian famine of 1928-29, of "compensatory practices." While these issues have yet to be clarified by scholars, documents about the extent and destination of the food aid rendered by the central government to the Ukrainian SSR at the height of the Holodomor in the spring of 1933 
demonstrate that the aid was absolutely insufficient and that its distinct targeting of certain categories of the population (the collective farmers) was intended to further purely pragmatic aims: to support carrying out the sowing and harvesting - that is, the further exploitation of Ukrainian grain resources.

In general, it is not of primary significance whether in the years of the first Five-Year Plan, grain and other food products were shipped out of Ukraine by order of the central government for export or to the union republics. In either or both cases, it was a matter of the ruination of Ukraine's economic base and the disorganization and exploitation of its grain resources to the advantage of the interests of the ruling metropolia, namely Moscow. According to the calculations of demographers, the victims of this policy in the Ukrainian SSR numbered some 3.9 million people. The highest level of mortality in Ukraine was in the first half of 1933, when about 3 million people died due to hunger (Rudnytskyi et al.).

\section{IMPERIAL/ANTI-COLONIAL IDENTITIES: SETTING A RESEARCH TASK}

In March 1927, the editorial offices of the newspaper Chervona armiia (Red Army) received a typical letter from a soldier of one of the regiments of the Ukrainian Military District describing the frequent clashes between Ukrainians and Great Russians over the Ukrainization policy. "The Russians are displeased with Ukrainization, but the Ukrainians defend it," wrote the author and then continued:

Thus, arguments begin. The Great Russians, even Komsomol members, say, "What good has that Ukrainization done, why is it necessary?" But there are bizarre Ukrainians who declare that if there is to be Ukrainization, then you have to Ukrainianize everything. Newspapers, literature-every last thing has to be Ukrainianized. So that there is nothing left in Russian. One nonParty Red Army soldier even declared, "What is your Lenin compared to Petliura?" (V. Hrynevych et al. 301).

The newspaper never published this unknown soldier's letter, but it did make it into one of the secret bulletins that, together with other similar documents, were compiled to inform the USSR's higher Party and government leadership of the social and political moods of the population in the various regions. In fact, the content of this letter was fairly symptomatic, for it reflected a situation that had been developing since the end of the nineteenth century, which, under the influence of the events of 1914-21, had become a reality. Its essence lay in the definitive affirmation of identity by Great Russians and Ukrainians, and the rapid consolidation, unexpected by 
many, of the latter as a separate nation, and moreover with a clear antipathy on a noticeable part of it towards the Soviet state project.

What remains often overlooked is that although the Ukrainian SSR had entered the union of Soviet republics, armed anti-Soviet units were active there until the middle of the 1920s. ${ }^{17}$ Relations between the government and the peasantry after the announcement of the New Economic Policy were rather wary, characterized by the expression "We've become used to it, we can somehow live and farm." "Ukrainian separatism," common among some of the intelligentsia, "cultivated" by the Ukrainian Autocephalous Orthodox Church, and rapidly disseminated among the student youth and in the countryside, remained a constant problem for the Bolshevik regime. Ukrainian nationalist attitudes, which were invariably characterized as manifestations of "Petliurism" and "Ukrainian chauvinism," simply could not be rooted out. Moreover, despite its specific ideological content, the policy of Ukrainization carried out by the Bolsheviks objectively accelerated the development of national consciousness among Ukrainians. So indeed did the slogans about a union of equal Soviet republics and their right to secede. The Ukrainian political emigration (chiefly the Government-in-exile of the Ukrainian People's Republic, located on the territory of the unfriendly neighbour Poland), also remained an irritating factor for the Bolsheviks. Its spokesmen declared the Soviet government in Ukraine illegitimate and worked against it, engaged in an information campaign in the West, and established and maintained illegal contacts on the territory of the Ukrainian SSR, carrying on intelligence and agitational activity.

The persistence of nationalist attitudes invites more questions related to attitudes and identities. Did the phenomena of imperial and anti-colonial identities exist in the USSR in general and in Soviet Ukraine specifically? If so, how widespread were they, how were they manifested, and how did they interact? Were anti-imperial and anti-colonial motifs present in the attitudes of the Ukrainian population with regard to the Stalinist faminogenic policies?

Researchers continue to explore the place and role of the Great Russians in the Soviet Union, particularly in Ukraine, as an "imperial ethnos." In the opinion of the Russian scholar Evgenii Anisimov, the acceptance of an imperial identity by ethnic Russians first in the Russian Empire, and then in the USSR, was obvious, and it was based on the perceptions that the Russian Empire was Russia, and that Russia was an empire; the Soviet Union, accordingly, was a great Russia with its "borderlands," where Great Russians and "others" live. With the victory of the Bolsheviks, notes this scholar, "new but essentially old" imperial stereotypes fit rather easily into the framework of imperial consciousness of the past: "proletarian messianism" with the

17 See Arkhireis'kyi; Bohan; Isakov; Krasnosilets'kyi; Plazova, Stehnii, and others. 
centre of the worldwide socialist republic in Moscow, "the empire as a fraternal, hierarchical family" headed by the elder brother, the Great Russian, as well as the complexes of "colonial ingratitude," the "innocence" of the Great Russian people, and so on (Anisimov).

Hosking holds a somewhat different view, emphasizing the complex identity of the Great Russians and stressing the considerable damage done to them by the imperial project. Although he does not define the Great Russians as an "imperial ethnos," the lengthy list he provides of factors that gave rise to feelings of national identity among the Russians in the USSR fits fully into the context of its most essential characteristics. In particular, the communist project was painted in noticeably Russian colours; its international messianism can be considered a Russian peculiarity, whose roots reach to the fifteenth-sixteenth century idea of Moscow as the Third Rome; the ideal of socio-economic egalitarianism, which was enshrined in the official ideology of the Soviet state, likewise had noticeably Russian traits; the status of a great state was a Russian concept; the territory of the USSR was nearly coterminous with the Russian Empire; the majority of Soviet leaders, especially after the 1930s, were Russians; the Russian language was the language of the state and the armed forces, and of international communication; finally, in the course of the Five-Year Plans, Russian specialists and workers settled in significant numbers throughout non-Russian regions. Although Russians did not have the status of a "master race," like the British in India, they nonetheless served as a constant reminder that in the Soviet Union, the Russians were the dominant ethnos (Hosking).

All in all, the scholarly problem of imperial/anti-imperial selfidentification in the USSR requires thorough research. Here, I focus on the dissemination of anti-imperial and anti-colonial attitudes among a discernible section of the Ukrainian population, chiefly of its largest stratum, the peasantry, with regard to the Stalinist policies of famine creation in 1928-29 and 1932-33. Although with the beginning of Stalin's "revolution from above," negative political activities of an anti-communist and antiSoviet bent were noticeable in all regions of the USSR, in Ukraine their distinctiveness lay in the interweaving of social and national motifs. A central theme from the beginning was the shipment of grain to Russia - the pillaging of Ukraine as the precondition and direct cause of the famine.

Already in March 1928, the leader of the republic's Party organization Lazar' Kaganovich admitted that in Ukraine, the initiation of extraordinary measures in the agrarian sphere had caused "a strengthening of chauvinism," and "not only from above, but also from below." In his speech to the Ukrainian Communist Party Central Committee plenum, he said, "We are having chats about how they are shipping grain and sugar out to Moscow .... The question about Moscow, about the Soviet Union, the questions to 
which Volobuiev gave profoundly false, untruthful and abominable answers, today are being posed keenly by the kulak" (RGASPI 81/3/108/13). On 16 July 1928, the new general secretary of the Ukrainian Communist Party Central Committee Stanislav Kosior took up this topic at a meeting of activists of the Kharkiv Party organization. "In Ukraine, some people are whispering," he noted, "that grain is supposedly being shipped out to Moscow. Without a doubt, these are rumours of counterrevolutionary, Petliurist origin. It is clear that our enemies are hammering away along this line" ("Pidsumky lypnevykh").

In conditions of the onset of famine in 1928-29, "uncomfortable" questions were being posed, judging from the numerous denunciations in the Ukrainian Communist Party Central Committee information department and summaries of the GPU (secret police), such as "Where did the grain harvested in Ukraine go?", "How did it happen that the granary is left without grain?", and "Why is an agricultural republic suffering famine?" These matters were the subject of vigorous discussions by various strata of the Ukrainian population, frequently connected with the disadvantages of Ukraine being in the USSR and the benefits of the status of an independent state. In this context, mentions of the Ukrainian governments of the Central Rada and the Directory, and of their leaders-chiefly Symon Petliura, a figure that symbolized the idea of an independent Ukrainian state-became widespread. Already in February-March 1928, the security services recorded conversations in units of the Ukrainian Military District that were typical in this regard. Angered by the grain requisitions and the financial pressure on their parents, peasant soldiers openly said, "It would be better if Ukraine separated from Russia. We would live better; but now, we have to give the grain to Russia, and she sells it abroad. So it turns out that Ukraine is being treated like a cow for the milking" (RGVA 9/28/58/174 verso); "It would be better for the peasantry if Ukraine were independent. Then we would govern our country and our people ourselves;" "The USSR is agitating for the Soviet Union because it is afraid of losing Ukrainian bread" (RGVA 25899/2/430/387). At the same time, in conversations among themselves the soldiers said that "The Central Rada would never have insulted the peasantry like the Soviet government does," and spoke in defence of Petliura, whom the political officers invariably portrayed at political lessons as a "bandit," "pogromist," and "traitor to the interests of Ukraine." "Petliura's government truly fought for the interests of Ukraine, but now all orders come from Russia, which lives at the expense of Ukraine," said the peasants (RGVA 25899/2/430/405). "Petliura did not have time to fully reveal himself, and who knows what he would have been like if he had stayed in power" (RGVA 9/28/81/2); "If we had Petliura, there would be enough of everything in Ukraine"(RGVA 25899/2/430/540). 
As the food supply situation became acute and hunger advanced, antiimperial and anti-colonial attitudes continued to spread among the population, not only in the Ukrainian countryside but also among the intelligentsia in the cities, and some of the workers as well. In May 1928, workers in the enterprises of the Odesa region were heard saying, "The government is shipping grain abroad while we are starving," and "Moscow is eating white bread that it takes out of Ukraine" (TsDAHO 1/20/2775/17). According to information provided by the secretary of the Poltava regional Party committee, during a meeting of 1,200 railroad workers in the summer of 1928, "independentist, kulak attitudes" were voiced, such as "the Poltava region is Ukraine's grain centre, but you have shipped everything to Moscow and Leningrad, and they are eating white bread there, while we do not even have black bread" (TsDAHO 1/20/2775/88-89).

Similar attitudes were especially widespread in the villages in the summer of 1928 and in the winter and spring of 1929. In the village of Sukhany, Bohodukhiv district in the Kharkiv region, conversations were recorded among the poor peasants to the effect that "Ukraine is starving, while Moscow is provided with white bread." These attitudes were also expressed by some Soviet activists. During a lecture on the international position of the USSR, Komsomol members in the village of Vasylytsia of the Cherkasy region began shouting, "Why are they telling us about the threat from abroad when Moscow is suffocating us?" And they asked at the same time, "Why is there such a difference: Russia, which is not agricultural, has bread at 17 kopeks a kilo, while Ukraine pays 10 kopeks for only a pound [1 pound $=0.4095 \mathrm{~kg}$ ]?" (TsDAHO 1/20/2989/6). In the village of Vodiane, Berestiv district in the Mariupol region, one of the local activists, a Party member, declared to the peasants: "Ukraine is a colony of Russia, from which it takes grain and taxes. They are squeezing the Ukrainians mercilessly" (TsDAHO 1/20/2989/11).

The attitudes of the more prosperous and middle layers of the peasantry in the village were even more radical. "How long will we remain under Russian rule?" heatedly asked one of the wealthy peasants in the village of Tarasivka of the Kupiansk district. "We have to separate from the Muscovites. Living with Russia is not good for us. We have a great deal of wealth, and Moscow takes everything" (TsDAHO 1/20/2989/25). Middlelevel peasants from the village of Bubnova Slobidka in the Cherkasy region were reported to have angrily said the following: "The katsaps [derogatory term for Russians] ship out everything they take from us, and we Ukrainians are hungry and barefoot. This will not last long, everything will be turned upside-down" (TsDAHO 1/20/2989/26). The middle-level peasants in the village of Ksendzivka in the Uman region seconded them: "They are clearing our Ukraine of grain and shipping it to Russia. Russia is cheating Ukraine: it 
takes grain and sugar, but it does not give us manufactured goods, and furthermore it starves us to death" (TsDAHO 1/20/3315/26).

The prevalence of these attitudes was characterized as "noticeable," "not rare," and those that appear "most frequently" and are "widespread" in reports of the Ukrainian Communist Party Central Committee information division and representatives of the security services in numerous summaries of the GPU. The following example is typical. On 1 November 1928, at a meeting of the Ukrainian Communist Party Central Committee, the plenipotentiary for grain procurement, Chaika, having just returned from the Shepetivka region, related that among the conversations he had heard was "that all the grain goes to Moscow, that they have turned Ukraine into a colony of Moscow." Chaika added: "Quite a few comrades speak about the broad dissemination of this Petliurist agitation; these conversations are fairly widespread" (TsDAHO 1/1/309/25-63; 1/20/2769/8-46, emphasis in the original).

Negative political attitudes among various strata of the Ukrainian population connected with the topic of the exploitation of Ukraine's grain resources by the central government were also recorded in the ensuing years. Revelatory conversations were constant among the peasant youth in the Red Army. In a private conversation with soldiers in February 1931, one of the younger commanders of the 31st rifle division explained the reasons for the impoverished life of the republic's population as follows:

If Ukraine were independent, then we would not have had to carry out collectivization. However much grain Ukraine gives to Russia, it will always be too little, and that is why here in Ukraine they brazenly seize the grain, regardless of the fact that we no longer have any, and give it to Russia-to those who are skinning us. (TsDAHO 1/20/3194/53)

A telling incident took place in Kharkiv on 26 February 1931, during the proceedings of the Thirteenth All-Ukrainian Congress of Soviets. A group of delegates and attendees at a forum of workers from Kharkiv factories (the Kharkiv locomotive works "Sickle and Hammer," among others) sent the presidium a resounding declaration containing a sharp criticism of the allUnion centre's policy toward Ukraine. The declaration essentially reflected anti-imperial and anti-colonial attitudes. It contained angry expressions against the ongoing "centralizing current," the extremely unequal division of wealth between the centre and the republic (they presented data indicating how in 1929 the Ukrainian SSR, with its population of 30 million, had the same budget as the region of Moscow, with its 5 million people), protesting against the limited powers of the Ukrainian government ("if it needs to do something, a sovereign republic does not bow down, yet we have to"). The declaration also pointed to the terrible conditions in the Ukrainian village ("barefoot, naked, hungry, humiliated, repressed, robbed a hundred times 
worse than they were robbed by the tsarist government, and worse than the greediest capitalist country robs its colonies"). The signatories drew a firm conclusion: "Russia is being built by the muscles of Ukrainian workers and peasants. Ukraine is collapsing" (TsDAHO 1/20/4171/10-19).

The continuing ruination of the Ukrainian countryside caused a further strengthening of negative political attitudes on the theme of Ukraine's colonial status. Masses of Ukrainian peasants went in search of bread to Moscow, Leningrad, Minsk, and other industrial centres better supplied with provisions than Ukraine. Conversations could be heard among various segments of the population about "Ukrainians begging" and noting that "for some reason, there is bread in Moscow, while in the Ukrainian cities it is practically impossible for the peasant to buy it." Party and government leaders, including Joseph Stalin, received letters of complaint. "I saw that in Russia a pud of bread costs 10 rubles, while in Ukraine it costs 80 karbovantsi. And there is none anyway, so everyone is going to Russia," wrote one Ukrainian peasant to Stalin (TsDAHO 1/20/5254/19). "I returned from the countryside two days ago and I saw all the misery there with my own eyes," wrote a rank-and-file Party worker from the Kyiv region to Stalin, adding that he himself was well fed in the Party dining-room. "It is painful to look at those unfortunate children and women perishing from hunger, waiting for their father to bring a loaf or two of bread from Moscow. For everyone is going to Moscow, Leningrad, and Minsk for bread" (TsDAHO $1 / 20 / 5254 / 12-13$ ). Similar letters were addressed to the Ukrainian Party and government leadership. "Food supply is well organized in the Russian part of the USSR ... the workers get white bread too, and there is no discussion about a lack of bread for the family," wrote one of the employees of the Liubotyn depot to Kosior. "National hatred is appearing in the Ukrainian workers' milieu .... Today you can easily say that 99 percent of the Ukrainian population has an anti-Soviet attitude" (TsDAHO $1 / 20 / 5406 / 4)$.

In the spring and summer of 1933, according to the observations of the secret service and Party workers, the degree of political protest in the Ukrainian countryside fell precipitously. The government's inaction in conditions of starvation, against the background of a Moscow-sanctioned information blockade, made a shocking impression on the populace and gave rise to a firm conviction among a part of it that the massive mortality of the Ukrainian population from hunger was no error in economic calculations but a purposeful act and predictable result of Ukraine's colonial status in the USSR. This was roughly the message of a letter from unknown residents of Poltava sent in August 1933 to the editors of the newspaper Komunist (The Communist): "The physical destruction of the Ukrainian nation, the exhaustion of its material and spiritual resources, is one of the most 
important points of the illegal program of Bolshevik centralism" (RGASPI $81 / 3 / 131 / 2$ ).

We thus see that a significant part of Ukrainian society perceived Stalin's faminogenic policies as imperial, conditioned by Ukraine's colonial status, and connected the proximate causes of impoverishment and mass mortality from hunger with inequality and the exploitation of Ukrainian grain resources.

Did bearers of imperial consciousness exist in Ukraine? Certainly, but scholars have yet to elucidate its manifestations during the famines of 192829 and 1932-33. It is obvious, nevertheless, that among both the central Bolshevik elite and parts of the peripheral elite that ruled Ukraine, antiUkrainian attitudes were common, while a significant portion of the nomenklatura (Party specialist elite) did not know or use the Ukrainian language. Among those who did use it, fear of being declared nationalists reigned as purges were a constant.

Another matter that deserves attention is the ideological and propaganda backdrop that existed on the eve of the Ukrainian catastrophe. The conviction of bringing civilization to a backward or barbaric country as seen in the colonial policies and practices of Europeans in Africa and Asia, and of the English in Ireland was to some degree apparent in the Soviet empire. As demonstrated in the classic work of S. Ambirajan Classical Political Economy and British Policy in India, state policy during the Indian famines of the nineteenth century leaves no doubt that the ideology of the bureaucracy (racist, colonial, imbued with a Malthusian spirit) made its negative contribution to mass famine. Racial and political elements of English imperialism were clearly manifest in the Bengal famine of 1943. In Churchill's Secret War, Madhusree Mukerjee demonstrates how Churchill's contempt for Indians (he called the Indians "a beastly people with a beastly religion," and Mahatma Gandhi a "harmful subversive fanatic") informed his callousness in the face of the sufferings of the starving in Bengal (78). Elaborating on Sen's analysis, Mukerjee asserts that Churchill's failure to act to stem the growing famine was part of a strategy of maintaining British domination in India and was conditioned by his indifferent, hostile, and disdainful attitude to the Indians, their beliefs, and their leaders. If English propaganda depicted the Indians and Irish as uncouth, uneducated, and filthy barbarians who needed to be civilized, the Bolsheviks in their propaganda masked the national aspect under that of class. Their propaganda presented Russian culture as progressive, forward-looking, and revolutionary ("the language of the workers"), destined to defeat a regressive, backward Ukrainian peasant culture with its obsolete traditions (even its national musical instruments the "kobza" and "bandura") and its "bumpkin language." Through the lens of three of the most disastrous famines in modern history - the potato famine in Ireland, the famine in 
Bengal in 1943, and the string of famines that plagued Ethiopia in the 1970s and 1980s-Thomas Keneally shows how ideology, mindsets of governments, racial preconceptions, and administrative incompetence were, ultimately, more lethal than the initiating blights or crop failures.

Following from this, it is worth paying attention in Soviet propaganda to efforts at how certain categories of the population were depicted as potentially hostile to the government. In this context it is worth analyzing how the "image of the enemy" was constructed. In constructing the image of the dehumanized "kulak enemy" (the negative connotation of which was often intensified by applying the label "Petliurist"), the regime prepared the population psychologically for the annihilation of an entire social stratum. The role of this "struggle of cultures" in the Ukrainian Holodomor, however, demands further illumination from future scholars.

\section{CONCLUSIONS}

The interpretation of the Soviet Union as a nation-state (prominent from Soviet times and still dominant in the historiography of the Stalinist policies of famine creation), excludes a priori the imperial essence of the Soviet Union, causing methodological limitations. In this article I have sought to demonstrate the applicability of models of dependence and imperialism to our understanding of the dynamics and consequences of the policy of collectivization of agriculture, and of famine at the end of the 1920s and first part of the 1930s, focusing on Soviet Ukraine.

The Stalinist faminogenic policies can be regarded as a means of consolidating the Soviet empire, which was secured by violence. Along with this, the appropriation of the sovereignty of the Ukrainian SSR by the central government, the clear asymmetry of relations along the "centre-periphery" axis, Moscow's total control over food resources (including determination of grain deliveries and distribution), the ongoing exploitation of Ukrainian economic resources against the backdrop of depriving the regional nomenklatura of even minimal liquid resources-together with the antiUkrainian terror-caused the Ukrainian famine of 1928-29 and may have been a critical factor in the onset of the Holodomor.

The degree of assimilation of an imperial mentality by the central and peripheral administrative elites remains an open question. Archival documents clearly indicate, however, that the Stalinist faminogenic policies were interpreted by parts of various strata of Ukrainian society (the peripheral elite, the peasants, the intelligentsia) as a manifestation of Moscow's imperial rule and Ukraine's colonial dependence. Documents also show that the central government monitored and repressed those who expressed such attitudes. 
The study of Stalinist famine-creation and of the tragedy of the Holodomor in the context of imperialism/colonialism is only beginning. In this, there is a similarity with Ireland, whose historians did not initially speak of a colonial factor in the Great Irish Famine. As the economic historian Cormac O'Grada pointed out at the beginning of the 1990s, the Gorta Mor of 1845-50 - causing a million deaths and two million to leave their native land-was at first attributed to natural cataclysms, leaving London's economic policies unmentioned or excused.

To summarize, I consider the Holodomor a genocide, a concept much questioned in the cases of Bengal and Ireland. In this regard, I am in absolute solidarity with the view of the American scholar Mark von Hagen that as was the cases of famine in Ireland in 1845-50 or in Bengal in 1943, imperialism was a factor in causing the Holodomor. Moreover, in the USSR the state and party dictatorship under Stalin provided the context and environment in which the ruling elites and their bureaucratic machines reached new-in essence the highest-levels of imperialism/colonialism (von Hagen). ${ }^{18}$

18 Holodomor Research and Education Centre in Ukraine, archive, 2017. 


\section{Works Cited}

5 s'ezd Sovetov. Biulleten' 17, zasedanie dvenadtsatoe, 27 May 1929.

Al'terman, A. Ia. "Problema tovarnosti zernovogo khoziaistva Ukrainy s sotsial'noekonomicheskoi tochki zreniia." Khoziaistvo Ukrainy, no. 6, 1928, pp. 101-110.

Ambirajan, S. Classical Political Economy and British Policy in India. Cambridge UP, 1978.

Anisimov, Ie. V. "Istoricheskie korni imperskogo myshleniia v Rossii." Slavic Research Center Winter Symposium Socio-Cultural Dimensions of the Changes in the SlavicEurasian World, 1996, http://srch.slav.hokudai.ac.jp/sympo/Proceed97/Anisimov.html. Accessed 26 Feb. 2020.

Applebaum, Anne. Red Famine: Stalin's War on Ukraine. Doubleday, 2017.

Arkhireis'kyi, D. V. Diial'nist' voiennykh narad Ukrainy v 1920-1924 rokakh (na materialakh pivdennykh hubernii). 2000. Dnipropetrovs'kyi derzhavnyi universytet, PhD dissertation (Dysertatsiia na zdobuttia nauk. stupenia kand. ist. nauk).

Baratov. Na iug! Na iug! Gosudarstvennoe izdatel'stvo, 1919.

Batalov, O. A. Imperiia iak typ sotsial'no-istorychnoi orhanizatsii. 2010. KhNU imeni V. N. Karazina, PhD dissertation (Avtoreferat dys. na zdobuttia nauk. stupenia kand. filosof. nauk).

Bohan, S. M. Povstans'kyi rukh v Odes'kii hubernii u 1920-1923 rokakh. 2003. Odes'kyi natsional'nyi universytet im. I. I. Mechnikova, PhD dissertation (Dysertatsiia na zdobuttia nauk. stupenia kand. ist. nauk).

Borisov, V. I., et al. Prodovol'stvennaia politika na Iuge Rossii v period pervoi mirovoi voiny i revolutsii (1914-1918): monografiia. 1997.

Borodaev, et al. "Proty burzhuazno-natsionalistychnoho shkidnytstva v s.-h. nautsi." Bil'shovyk Ukrainy, no. 11, 1933, pp. 116-24.

Borys, Jurij. The Sovietization of Ukraine 1917-1923: The Communist Doctrine and Practice of National Self-Determination. Revised ed., Canadian Institute of Ukrainian Studies, 1980.

Cameron, Sarah. The Hungry Steppe: Famine, Violence, and the Making of Soviet Kazakhstan. Cornell UP, 2018.

Chernov, M. "Pytannia khlibnoho eksportu Ukrainy.” Visti VUTsVK, 5 Jan. 1928.

Davies, R. W., and Stephen G. Wheatcroft. The Years of Hunger: Soviet Agriculture, 1931-1933. 1st ed., Palgrave Macmillan, 2004. The Industrialisation of Soviet Russia $5 . \quad$ Available online: https://eastsidemarxism.files.wordpress.com/2017/04/r-w-davies-stephen-gwheatcroft-the-industrialisation-of-soviet-russia-volume-5-the-years-ofhunger-soviet-agriculture-1931-1933.pdf. Accessed 26 Feb. 2020.

Den, V. E. Polozheniie Rossii v mirovom khoziaistve. Analiz russkogo eksporta do voiny: statisticheskii ocherk. Severo-zapadnoe promyshlennoe biuro V.S.N.Kh. 1922.

Doyle, Michael W. Empires. Cornell UP, 1986.

Dyrektoriia, Rada Narodnykh Ministriv Ukrain'skoi Narodnoi Respubliky 1918-1920: Dokumenty i materialy. Vyd-vo Oleny Telihy, 2006. 2 vols.

Edgar, Adrienne Lynn. Tribal Nation: The Making of Soviet Turkmenistan. Princeton UP, 2004.

Etkind, Alexander. Internal Colonization: Russia's Imperial Experience. Polity, 2011. 
Ezhegodnik khlebooborota za 1931-32, 1932-33 i predvaritel'nye itogi zagotovok 1933 g. (tablitsy). Komitet po zagotovkam s.-kh. Produktov pri SNK SSSR, 1934.

Frumkin, M. I. Narodnoe khoziaistvo i vneshniaia torgovlia SSSR. Gosizdat, 1926.

Graziosi, Andrea. "The Soviet 1931-1933 Famines and the Ukrainian Holodomor: Is a New Interpretation Possible, and What Would Its Consequences Be?" Harvard Ukrainian Studies, vol. 27, no. 1/4, 2004-05, pp. 97-115. DOI: 10.2307/41036863

Hirsch, Francine. Empire of Nations: Ethnographic Knowledge and the Making of the Soviet Union. Cornell UP, 2005. Culture and Society after Socialism.

Hosking, Geoffrey. Rulers and Victims: The Russians in the Soviet Union. Belknap Press, 2006.

Hrynevych, Liudmyla. Holod 1928-1929 rr. u radians'kii Ukraini. Instytut istorii Ukrainy NAN Ukrainy, 2013.

Hrynevych, V., et al. Istoriia ukrains'koho viis'ka: 1917-1995. Compiled by Ia. Dashkevych, Vydavnytstvo "Svit," 1996.

Hunczak, Taras, editor. The Ukraine 1917-1921: A Study in Revolution. Harvard Ukrainian Research Institute, 1977.

Iakovenko, I. G. "Ot imperii $\mathrm{k}$ natsional'nomu gosudarstvu (Popytka kontseptualizatsii protsessa)." Polis, no. 6 (36), 1996, pp. 117-28.

Iefimenko, Hennadii. Vzaiemovidnosyny Kremlia ta Radian'skoi Ukrainy: Ekonomichnyi aspekt (1917-1919 pp.). Instytut istorii Ukrainy NAN Ukrainy, 2008.

Isakov, P. M. Selian'skyi povstans'kyi rukh na Livoberezhnii Ukraini (berezen' 1919lystopad 1921 rr.). 2001. NAN Ukrainy / Instytut istorii Ukrainy, PhD dissertation (Dysertatsiia na zdobuttia nauk. stupenia kand. ist. nauk).

Kak lomali NEP. Stenogrammy plenumov TsK VKP(b) 1928-1929 gg. V 5-ti tomakh. Vol. 3: Plenum TsK VKP(b) 16-24 noiabria $1928 \mathrm{~g}$. Mezhdunarodnyi fond "Demokratiia," 2000.

Kappeler, Andreas. Rosiia iak polietnichna imperiia. Vyd-vo Katolyts'koho Ukrains'koho universytetu, 2005.

---. The Russian Empire: A Multi-Ethnic History. Routledge, 2001. Available online: https://www.taylorfrancis.com/books/9781315736792. Accessed 26 Feb. 2020.

Kaspe, Sviatoslav. Imperiia i modernizatsiia. Obshchaia model' i rossiiskaia spetsifika. ROSSPEN, 2001.

Keneally, Thomas. Three Famines: Starvation and Politics. Random House/Knopf Australia, 2010.

Khalid, Adeeb. Making Uzbekistan: Nation, Empire, and Revolution in the Early USSR. Cornell UP, 2015.

Kindler, Robert. Stalin's Nomads. Power and Famine in Kazakhstan. Pittsburgh UP, 2018.

Kondrashin, V. Khlebozagotovitel'naia politika $v$ gody pervoi piatiletki i ee rezul'taty (1929-1933 gg.). Politicheskaia entsiklopedia, 2014.

Kononenko, K. Ukraina i Rosiia: Sotsiial'no-ekonomichni pidstavy ukrains'koi natsional'noi idei. 1965.

Kontrol'nye tsifry narodnogo khoziaistva USSR na 1928-29 god. Izd-vo Gosplana USSR, 1928. 
Kosheleva, L. et al., editors. Pis'ma I. V. Stalina V. M. Molotovu. 1925-1936 gg. (Sbornik dokumentov). Rossiia molodaia, 1996.

Krasnosilets'kyi, D. P. Antybil'shovyts'kyi rukh selian v Pravoberezhnii chastyni USRR u 1920-1924 rokakh. KhNU, 2009.

Kulchytsky, Stanislav. The Famine of 1932-1933 in Ukraine: An Anatomy of the Holodomor. CIUS P, 2018.

Kul'chyts'kyi, S. Chervonyi vyklyk. Istoriia komunizmu v Ukraini vid ioho narodzhennia do zahybeli. Tempora, 2013. 3 vols.

Lenin, V. I. Povne zibrannia tvoriv. Vol. 50, Vydavnytstvo politychnoi literatury Ukrainy, 1975.

Lieven, Dominic. Empire: The Russian Empire and Its Rivals. Yale UP, 2001.

Mace, James E. Communism and the Dilemmas of National Liberation: National Communism in Soviet Ukraine, 1918-1933. Harvard Ukrainian Research Institute, 1983. Harvard Series in Ukrainian Studies.

Makuch, Andrij, and Frank E. Sysyn, editors. Contextualizing the Holodomor: The Impact of Thirty Years of Ukrainian Famine Studies. CIUS P, 2015.

Malynovs'kyi, B. V. Ahrarna polityka Avstro-Uhorshchyny ta Nimechchyny v Ukraini, 1918 r. 2001. Dnipropetrovs'kyi natsional'nyi universytet, PhD dissertation (Avtoreferat dys. na zdobuttia nauk. stupenia kand. ist. nauk).

Marcus, David. "Famine Crimes in International Law." The American Journal of International Law, vol. 97, no. 2, April 2003, pp. 245-81. DOI: 10.2307/3100102

Marochko, V. "Sprava 'Kontrrevoliutsiinoi shkidnyts'koi orhanizatsii v sil's'komu hospodarstvi USRR': mekhanizm i naslidky teroru." $Z$ arkhiviv VUChK-GPUNKVD-KGB, no. 1/2 (6/7), 1998, pp. 96-104.

Martin, Terry. The Affirmative Action Empire: Nations and Nationalism in the Soviet Union, 1923-1939. Cornell UP, 2001. Wilder House Series in Politics, History and Culture.

Motyl, Alexander J. Imperial Ends: The Decay, Collapse, and Revival of Empires. Columbia UP, 2001.

Motyl', Oleksandr (Alexander J. Motyl). "SRSR iak Rosiis'ka imperiia. Chym bula radians'ka Ukraina?” Tyzhden', no. 46 (263), 15 Nov. 2012, https://tyzhden.ua/History/65141. Accessed 26 Feb. 2020.

Mukerjee, Madhusree. Churchill's Secret War: The British Empire and the Ravaging of India during World War II. Basic Books, 2010.

Mytsiuk, O. Pro avtonomiiu Ukrainy v federatyvnii Rosii. Druk. V. Levitans'koho, 1917.

Narodnoe khoziaistvo Ukrainy v 1921 g. Otchet Ukrainskogo Ekonomicheskogo Soveta Sovetu Truda i Oborony. 4-ia gosudarstvennaia tipografiia, 1922.

"Na Ukraini zahotovleno 260,2 mil. pudiv khliba. Richnyi plan zahotivel' vykonano na 98,2\%." Visti VUTsVK, 4 July 1928.

"Na zahal'nu dopovid' pro piatyrichnyi plan narodnoho hospodarstva Ukrainy: postanovy XI Vseukrains'koho z'izdu rad robitnychykh, selians'kykh i chervonoarmiis'kykh deputativ, 15 travnia 1929 r." Visti VUIVK, 12 June 1929.

Ó Gráda, Cormac. The Great Irish Famine. Cambridge UP, 1995.

"O piatiletnem plane razvitiia narodnogo khoziaistva: postanovlenie V s"ezda Sovetov SSSR. 28 maia 1929 g." Sobranie zakonov i rasporiazhenii. Otdel 1, no. 35,1929, p. 311. 
Piatiletnii plan narodno-khoziaistvennogo stroitel'stva SSSR. Vol. 3, Izdatel'stvo "Planovoe khoziaistvo," 1930.

"Pidsumky lypnevykh plenumiv TsK VKP(b) ta TsK LKSMU: dopovid' heneral'noho sekretaria TsK KP(b)U tov. St. Kosiora na zborakh aktyvu Kharkivs'koi partorhanizatsii 16 lypnia 1928 r." Komunist, 18 July 1928.

Plazova, T. I. Ukrains'kyi Partyzans'ko-Povstans'kyi Shtab ta ioho uchast'v orhanizatsii antybil'shovyts'koi borot'by $v$ Ukraini (1920-1921 rr.). 2005. Natsional'nyi universytet "L'vivs'ka politekhnika," PhD dissertation (Dysertatsiia na zdobuttia nauk. stupenia kand. ist. nauk).

Popov, F. "Problemy ahrarnoi perenaselenosti ta shliakhy rozvytku narodn'oho hospodarstva USRR." BIl'shovyk Ukrainy, nos. 21-22, 1928, pp. 64-76.

Problemy rekonstruktsii narodnogo khoziaistva SSSR na piatiletie: piatiletnii perspektivnyi plan na V s"ezde Gosplanov. Planovoe khoziaistvo, Gosplan SSSR, 1929.

Rafalovs'kyi, Ie. P. Prodovol'cha polityka uriadiv Ukrains'koi Derzhavy het'mana Petra Skoropads'koho. 2007. Natsional'nyi pedahohichnyi universytet im. M. P. Drahomanova, PhD dissertation (Avtoreferat dys. na zdobuttia nauk. stupenia kand. ist. nauk).

Reshetar, John S. The Ukrainian Revolution, 1917-1920: A Study in Nationalism. Princeton UP, 1952.

Rudnytskyi, Omelian, et al. "Demography of a Man-Made Human Catastrophe: The Case of Massive Famine in Ukraine 1932-1933." Canadian Studies in Population, vol. 42, no. 1-2, 2015, pp. 53-80. DOI: 10.25336/P6FC7G

Sahni, Kalpana. Crucifying the Orient. Russian Orientalism and the Colonization of Caucasus and Central Asia. White Orchid Press, 1997.

Sen, Amartya. Poverty and Famines: An Essay on Entitlement and Deprivation. Oxford UP, 1981.

S"ezdy Sovetov Soiuza Sovetskikh Sotsialisticheskikh Respublik. Sbornik dokumentov. 1922-1936 gg. Compiled by D. A. Gaidukov et al., 1960.

Shevchenko, A. M. Zovnishnia torhivlia portiv na Pivdni Ukrainy (druha polovyna XIXpochatok $X X$ st.). 2008. Izmail's'kyi derzhavnyi humanitarnyi instytut, $\mathrm{PhD}$ dissertation (Dys. na zdobuttia nauk. stupenia kand. ist. nauk).

Slezkine, Yuri. Arctic Mirrors: Russia and the Small Peoples of the North. Cornell UP, 1996.

Sobranie zakonov i rasporiazhenii. Otdel 1, no. 29 and no. 35, 1929.

Soloveichik, V. M. (V. M. Soloveichyk) "Osnovnye voprosy 5-letnego plana rekonstruktsii sel'skoho khoziaistva USRR.” Khoziaistvo Ukrainy, no. 10, 1928, pp. 25-43.

"Sovershenno sekretno": Lubianka-Stalinu o polozhenii v strane (1922-1934 gg). Sbornik dokumentov v 10 tomakh. Vol. 7: 1927, Institut Rossiiskoi istorii RAN, 2004.

Sovetskaia derevnia glazami VChK-OGPU-NKVD. Dokumenty i materialy v 4-kh tomakh. Vol. 2: 1923-29. ROSSPEN, 2000.

Sprava 'Ukrains'koi filii Trudovoi selians'koi partii." Holovna redkolehiia "Reabilitovani istorieiu," 2010.

Stebnitskii, P. Ia. (Petro Stebnyts'kyi). Ukraina $v$ ekonomike Rossii. 8-ia Gosudarstvennaia tipografiia, 1918. 
Stehnii, P. A. Selians'ki povstannia v Pravoberezhnii chastyni USRR u 1921-1923 rr. (na materialakh petliurivs'koho rukhu). 2000. Kremenchuts'kyi derzhavnyi politekhnichnyi instytut, $\mathrm{PhD}$ dissertation (Dysertatsiia na zdobuttia nauk. stupenia kand. ist. nauk).

Suni, Ronald (Ronald Suny). "Dialektika imperii: Rossiia i Sovetskii Soiuz." Novaia imperskaia istoriia postsovetskogo prostranstva, edited by I. Gerasimov et al., Kazan, "Tsentr Issledovanii Natsionalizma i Imperii," 2004, pp. 163-96.

Tauger, Mark B. "Grain Crisis or Famine? The Ukrainian State Commission for Aid to Crop-Failure Victims and the Ukrainian Famine of 1928-1929." Provincial Landscapes: Local Dimensions of Soviet Power, 1917-1953, edited by D. J. Raleigh, U of Pittsburgh P, 2001, pp. 146-70.

Tishkov, Valerii. “Chto est' Rossiia i rossiiskii narod.” Pro et Contra, May-June 2007, pp. 21-41.

Thompson, Ewa. Imperial Knowledge: Russian Literature and Colonialism. Greenwood, 2000.

Thompstone, Stuart Ross. The Organisation and Financing of Russian Foreign Trade before 1914. 1991. University of London, PhD dissertation.

Ukrains'ka Tsentral'na rada: Dokumenty i materialy. Vol. 1: 4 bereznia-9 hrudnia 1917 r. Naukova dumka, 1996.

---. Vol. 2: 10 hrudnia 1917 r.-29 kvitnia 1918 r. Naukova dumka, 1997.

Vasyl'iev, V. Politychne kerivnytstvo URSR i SRSR: dynamika vidnosyn "tsentr-subtsentr vlady" (1917-1938 rr.). Instytut istorii Ukrainy NAN Ukrainy, 2014.

V. I. Lenin pro Ukrainu. Part II: 1917-1922. Politvydav Ukrainy, 1969.

Vishnevskii, A. A. Serp i rubl'. Konservativnaia modernizatsiia v SSSR. OGI, 1998.

Vol'f, M. B., and G. A. Mebus. Statisticheskii spravochnik po ekonomicheskoi geografii SSSR i drugikh gosudarstv. Gosudarstvennoe izdatel'stvo, 1926.

Volobuiev, M. "Do problemy ukrains'koi ekonomiky." Dokumenty ukrains'koho komunizmu, 1962, pp. 132-230.

---. "Lyst do zhurnalu 'Bil'shovyk Ukrainy.'” Bil'shovyk Ukrainy, nos. 21-22, 1928, pp. 147-48.

von Hagen, Mark. "Holodomor i Holokost iak 'naivyshchi stadii' kolonializmu." Institute of the History of Ukraine / National Academy of Sciences of Ukraine, 23 Sept. 2015. Holodomor Research and Education Centre in Ukraine, Audiovisual Archive of the Holodomor Era. Public lecture.

Zbirnyk uzakonen' ta rozporiadzhen'. Viddil pershyi, no. 143, art. 99, 1929. 


\section{Archives}

DAKhO State Archive of the Kharkiv Oblast (cited by fond/opys/odynytsia zberihannia/arkush)

RGASPI Russian State Archive of Social-Political History (cited by fond/opis'/delo/list)

RGVA Russian State Military Archive (cited by fond/opis'/delo/list)

TsA FSB RF Central Archive of the Federal Security Service of the Russian Federation (cited by fond/opis'/delo/list)

TsDAHO Central State Archive of Civic Associations of Ukraine (cited by fond/opys/sprava/arkush)

TsDAVO Central State Archive of Higher Organs of Government and Administration (cited by fond/opys/sprava/arkush) 